\title{
Adult Perceptions of Student Involvement in Schoolyard Gardening
}

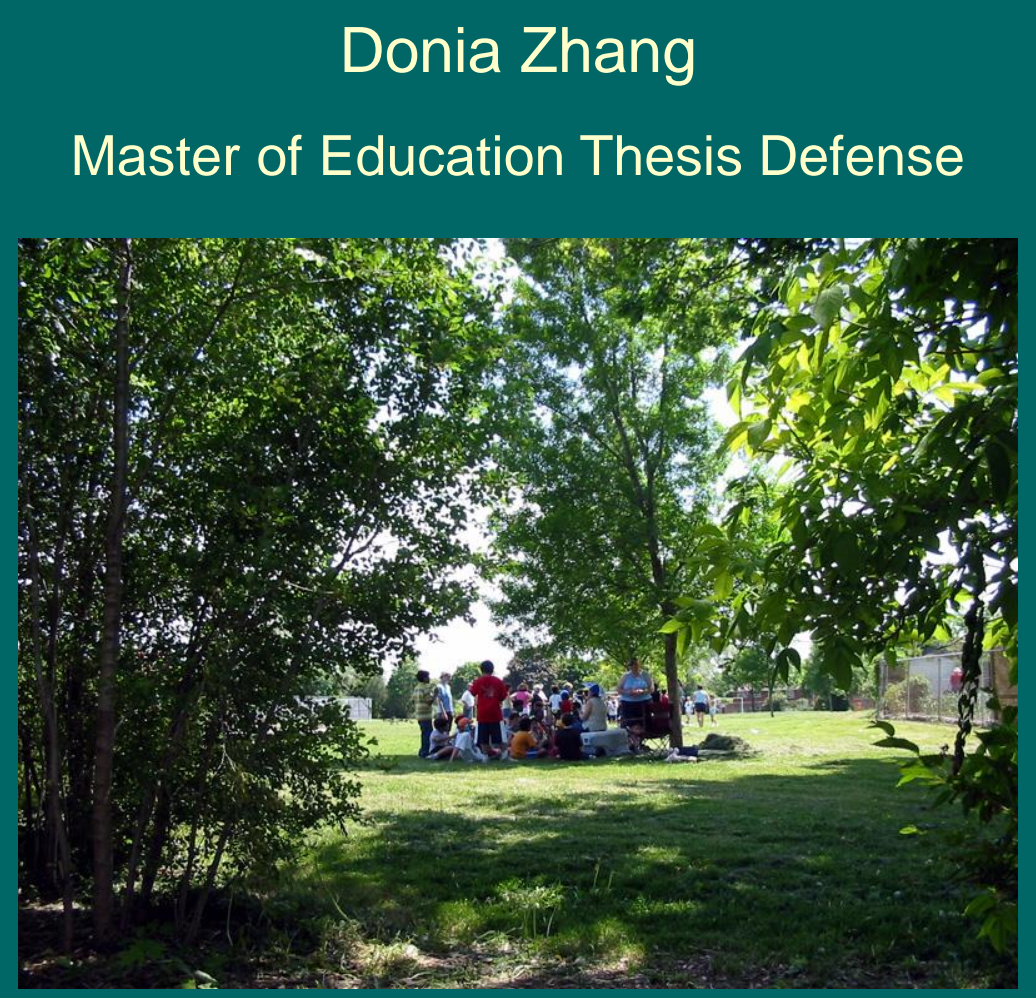

Faculty of Education, Brock University

October 18, 2005 


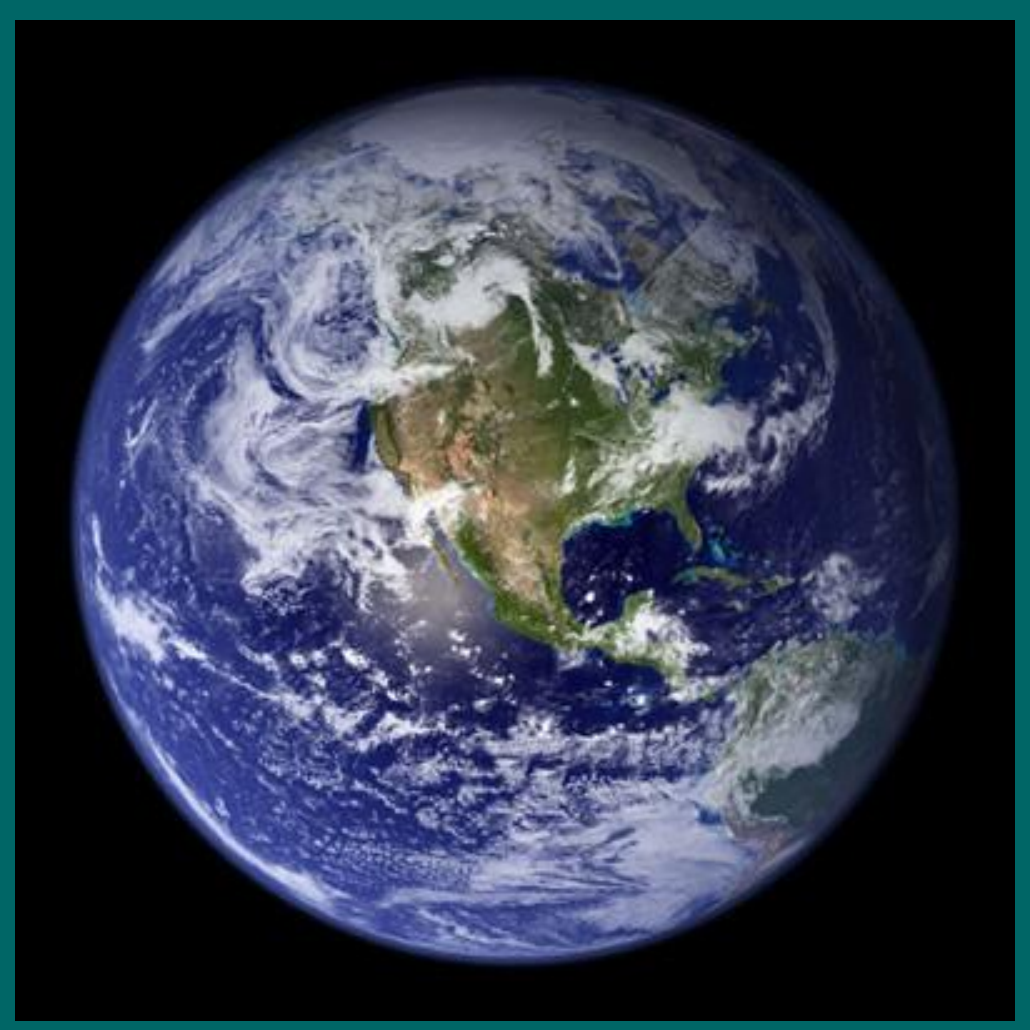

To Mother Earth

You breed thousands of children with your abundant bread; Yet you expect nothing in return but deep, deep respect.

- Donia Zhang, March 2005 


\section{Why Gardens?}

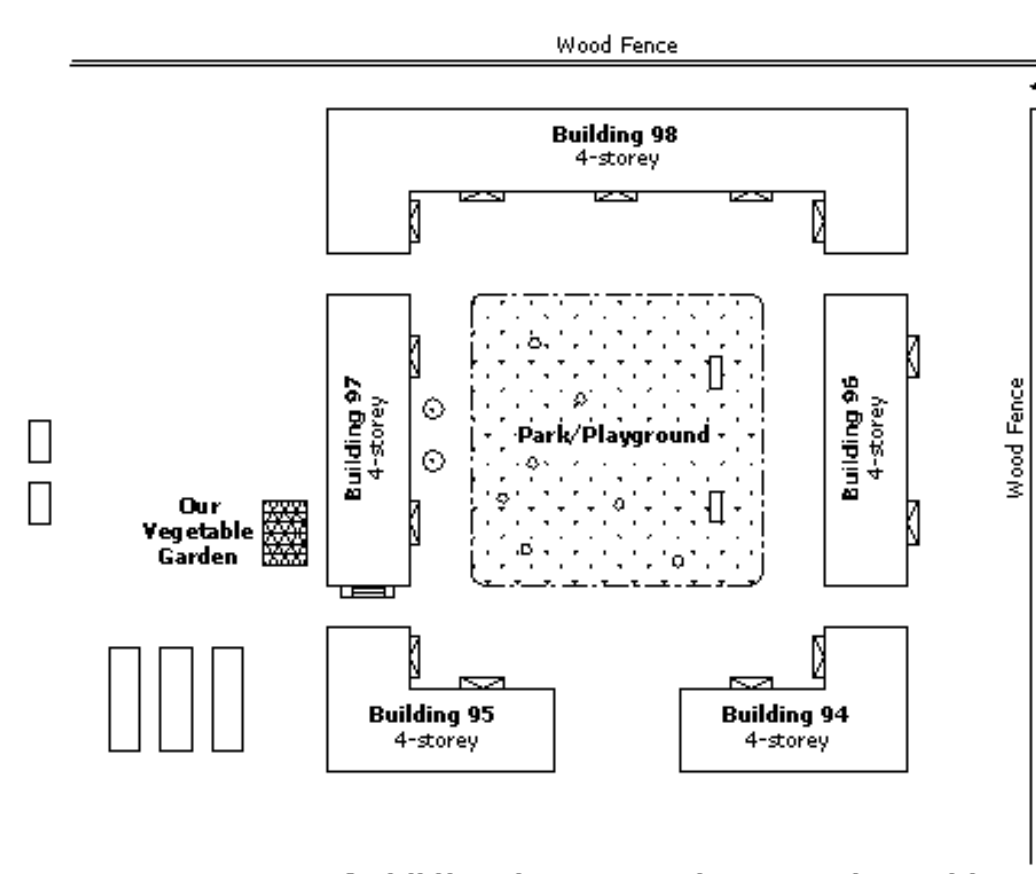

My Memory of Childhood Home Environment in Harbin (Drawn by Donia Zhang, July 15, 2005)

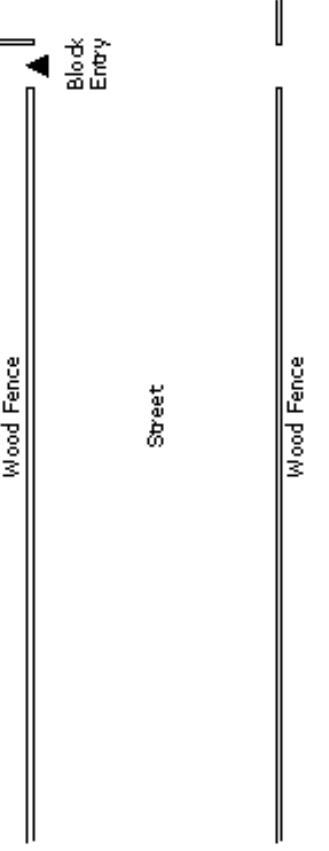

My initial interest in gardens may derive from my childhood experience in China. My memory of childhood home environment in Harbin. Drawing by Donia Zhang 


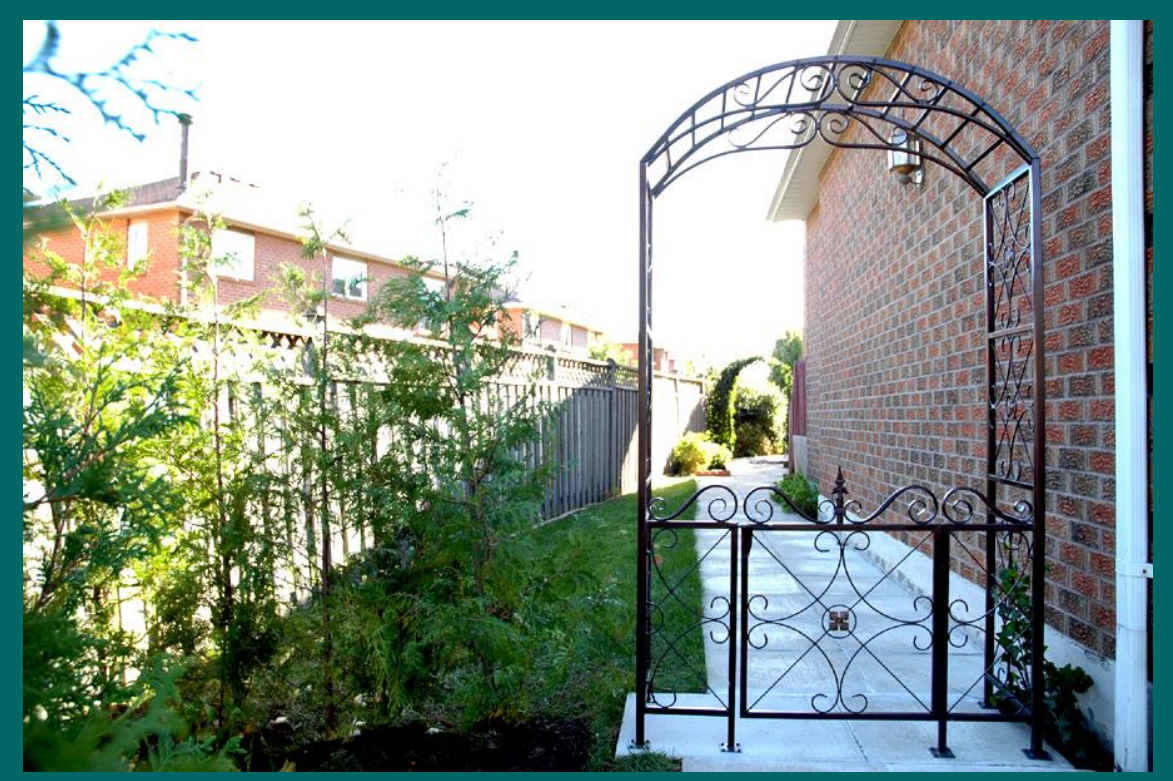

Our garden gate and cedar trees

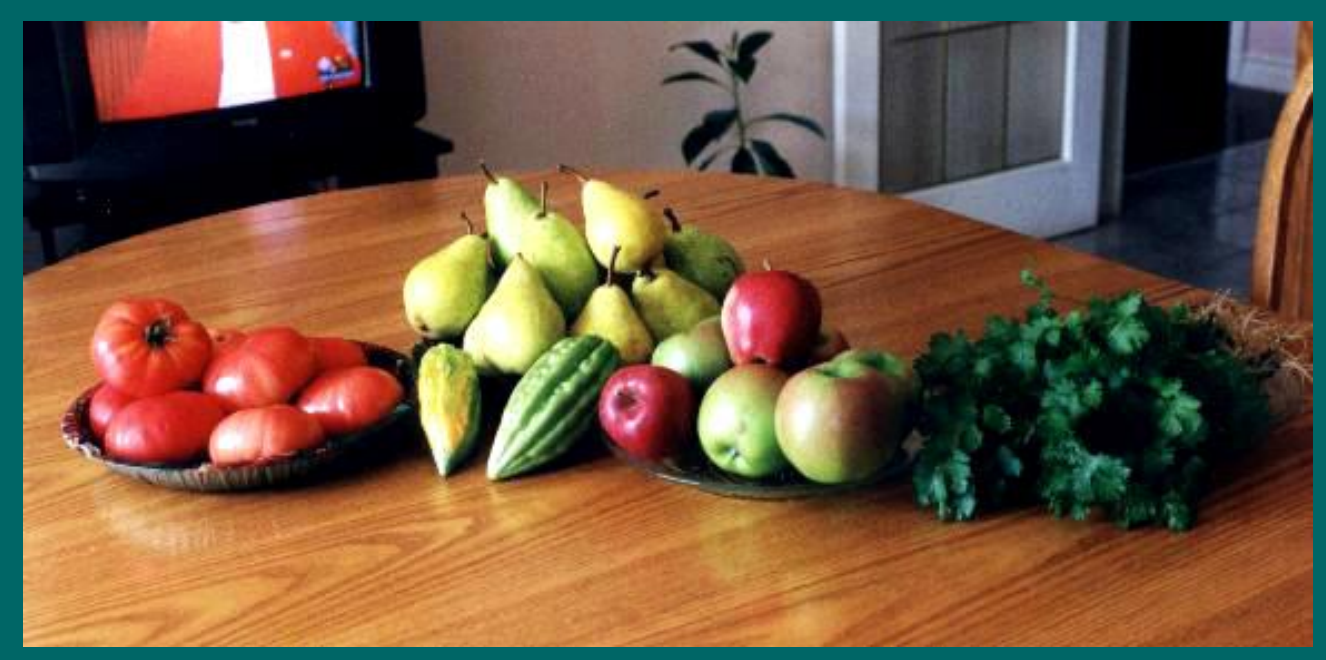

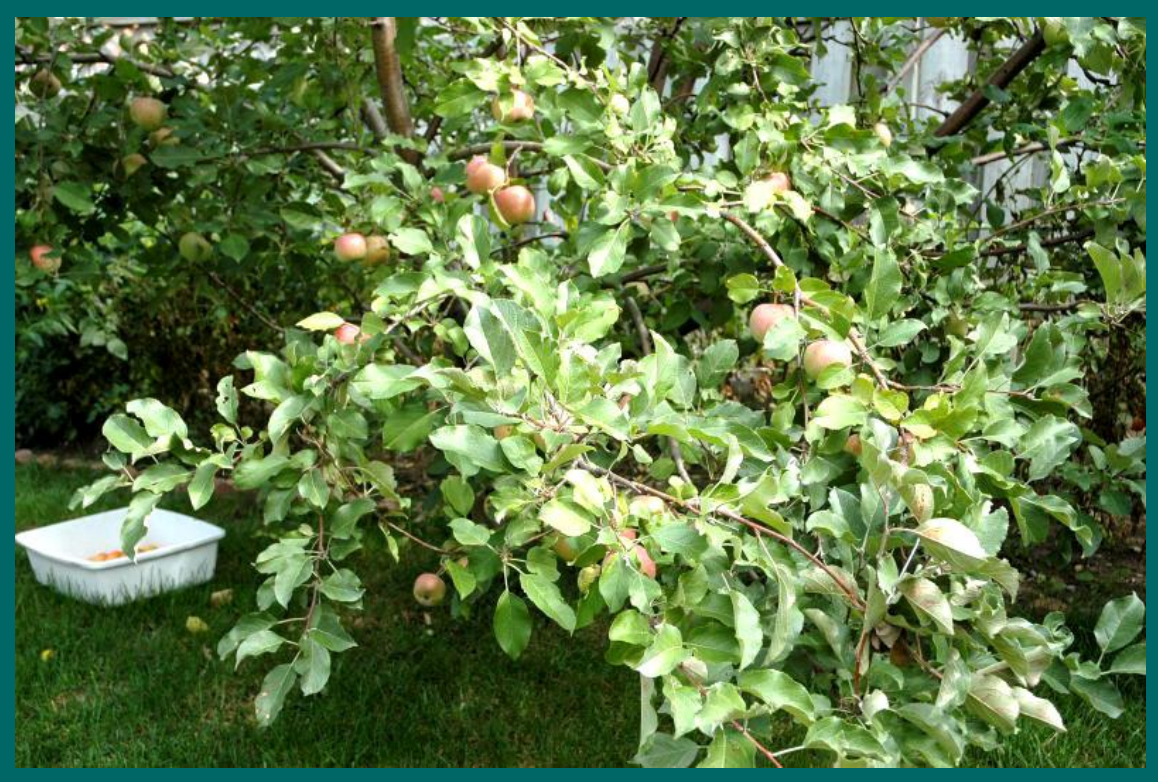

Apple harvest, October 2005

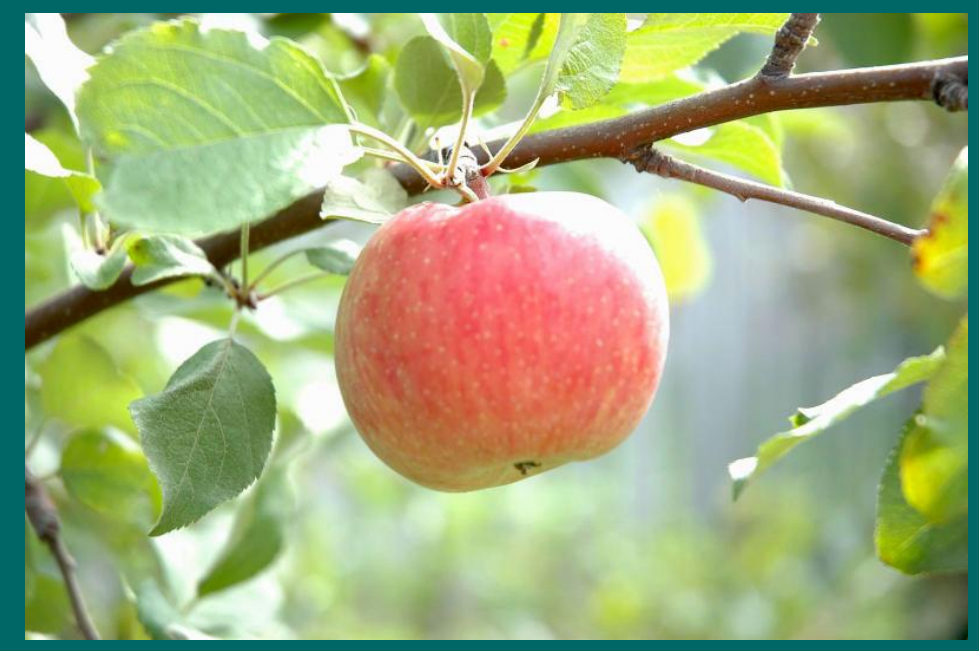

Our backyard 'Vegetable and Fruit Garden' in Richmond Hill, Ontario, Canada 


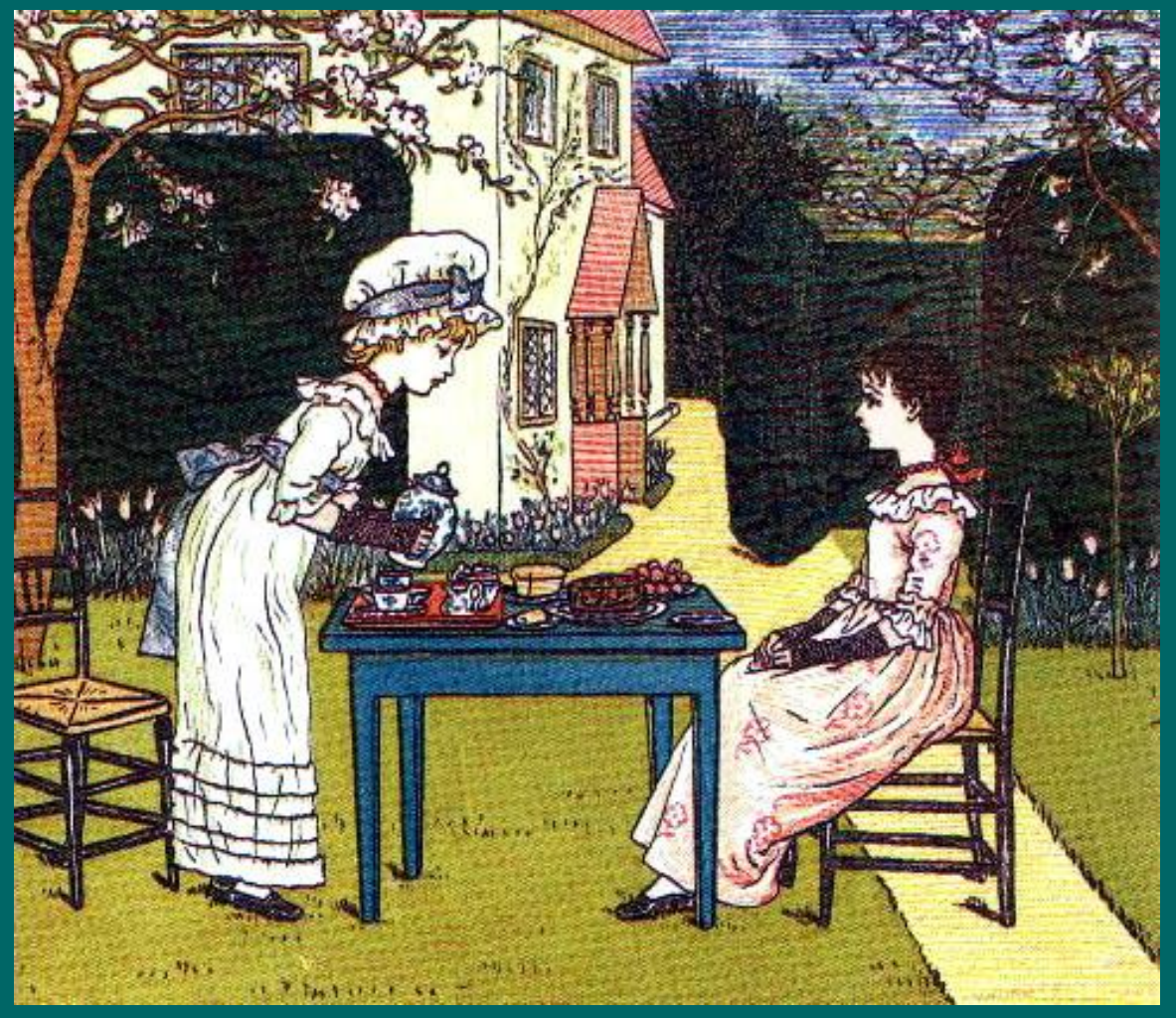

Having tea and fruits in a garden strengthens a friendship. Image Source: Children and Gardens by Gertrude Jekyll, 1982/1984/1990

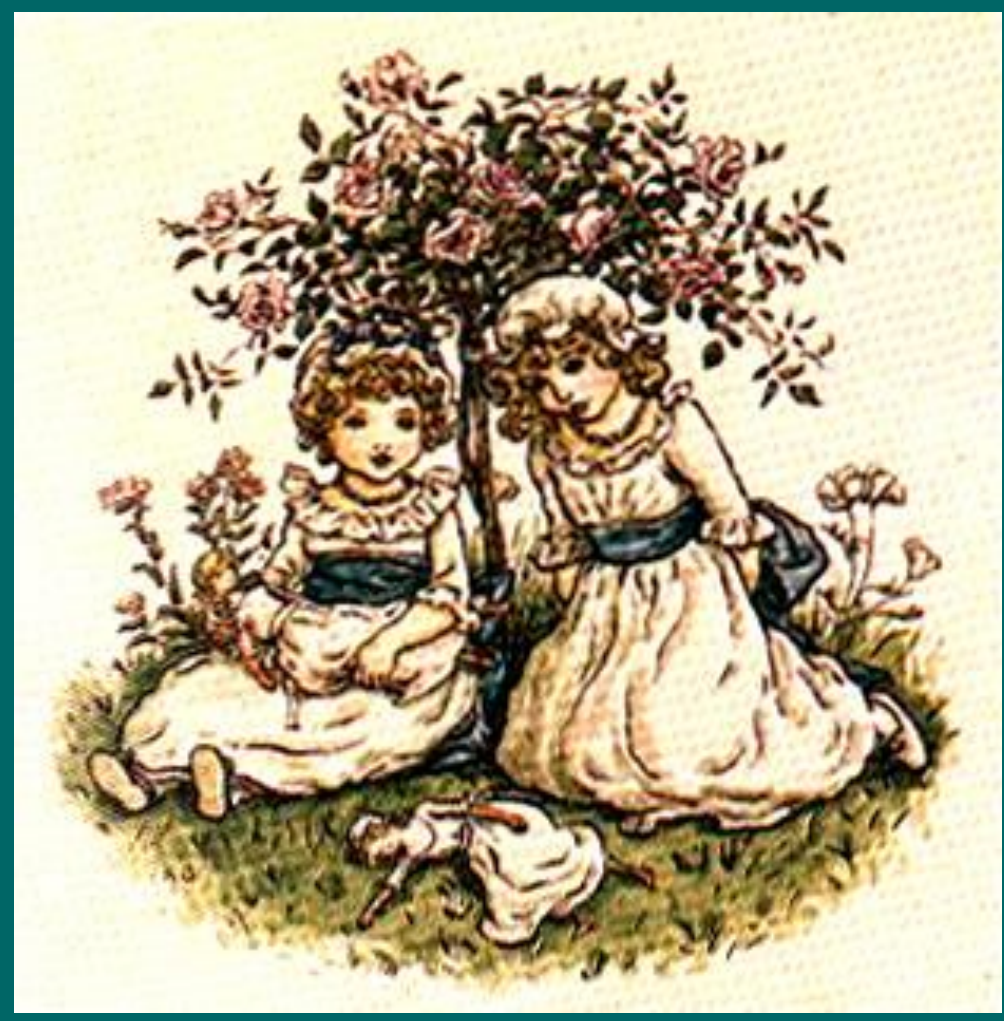

Image Source: Children and Gardens by Gertrude Jekyll, 1982/1984/1990

$>$ A garden is a form of art that is related to nature as well as culture

$>$ In a garden, art and science, mind and nature, finally intersect 


\section{Background of the Problem}

${ }^{\text {The }} \mathrm{GIFT}^{\circ}{ }^{\circ} \mathrm{GOOD}$ LAND

This research study is in response to the UNESCO's call for environmental education to raise young people's environmental awareness and to reconnect them with the natural world.

$>$ Environmental Crisis of the Modern World

$>$ Human Disconnection from the Natural World

$>$ Environmental Education for the Postmodern Era

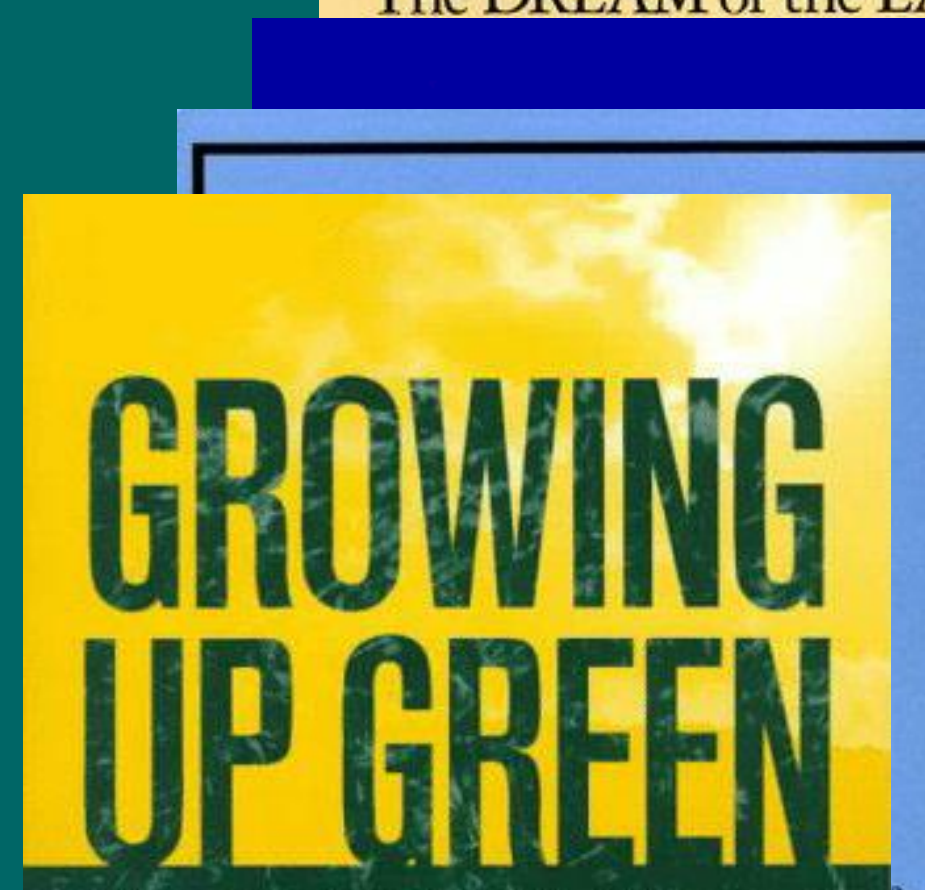

\section{Education for Eecological Renewal}

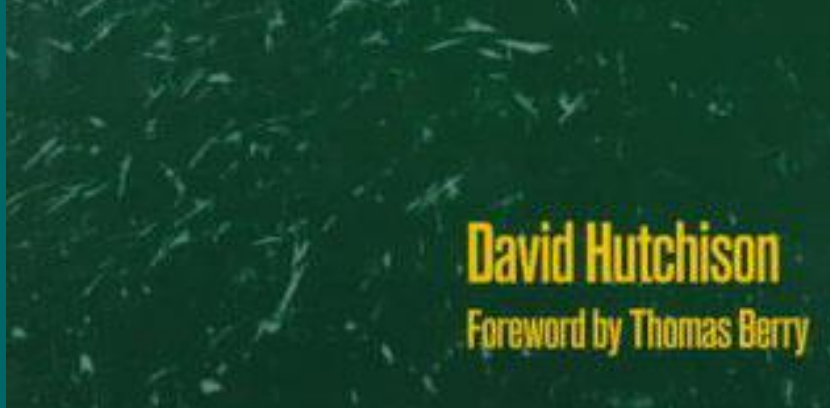




\section{Statement of the Problem}

This thesis examines the factors that have enabled and limited student participation in schoolyard gardening through the perceptions of adults, because:

$>$ Previous research findings revealed that there is a lack of student involvement in schoolyard gardening, especially in the initial planning and design stage

$>$ Dyment (2004) found that students in the Toronto District School Board (TDSB) are not involved in school ground greening nearly as much as they should be

$>$ There has been no detailed Canadian research study on adult perceptions of student involvement in schoolyard gardening 


\section{Statement of the Purpose}

The purpose of this research is to investigate through adult perceptions:

$>$ What factors have enabled and limited student participation in schoolyard gardening?

$>$ How can schools support student involvement in schoolyard gardening?

$>$ It is a follow-up study of the Canadian researcher Janet E. Dyment's PhD dissertation, Greening School Grounds in the Toronto District School Board: An Investigation of Potential (2004)

$>$ It is a collective case study of three TDSB schools that were running a schoolyard gardening project 


\section{Rationale for the Study}

$>$ Studying adult perceptions of student involvement is the best way to tackle this issue since the power and decision-making rest very much in the hands of adults

$>$ Interviewing students would require additional parental consents and audio transcriptions, which could be difficult to accomplish within the timeframe for a Master's thesis 


\section{Research Questions}

My research questions are as follows:

1. From the perceptions of adults, what is the amount of student participation in schoolyard gardening and at what stage are students mostly involved?

2. From the perceptions of adults, what are the factors that have enabled and limited student participation in schoolyard gardening?

3. From the perceptions of adults, how can schools maximize the enabling factors and minimize the limiting factors for student involvement in schoolyard gardening? 


\section{Theoretical Framework}

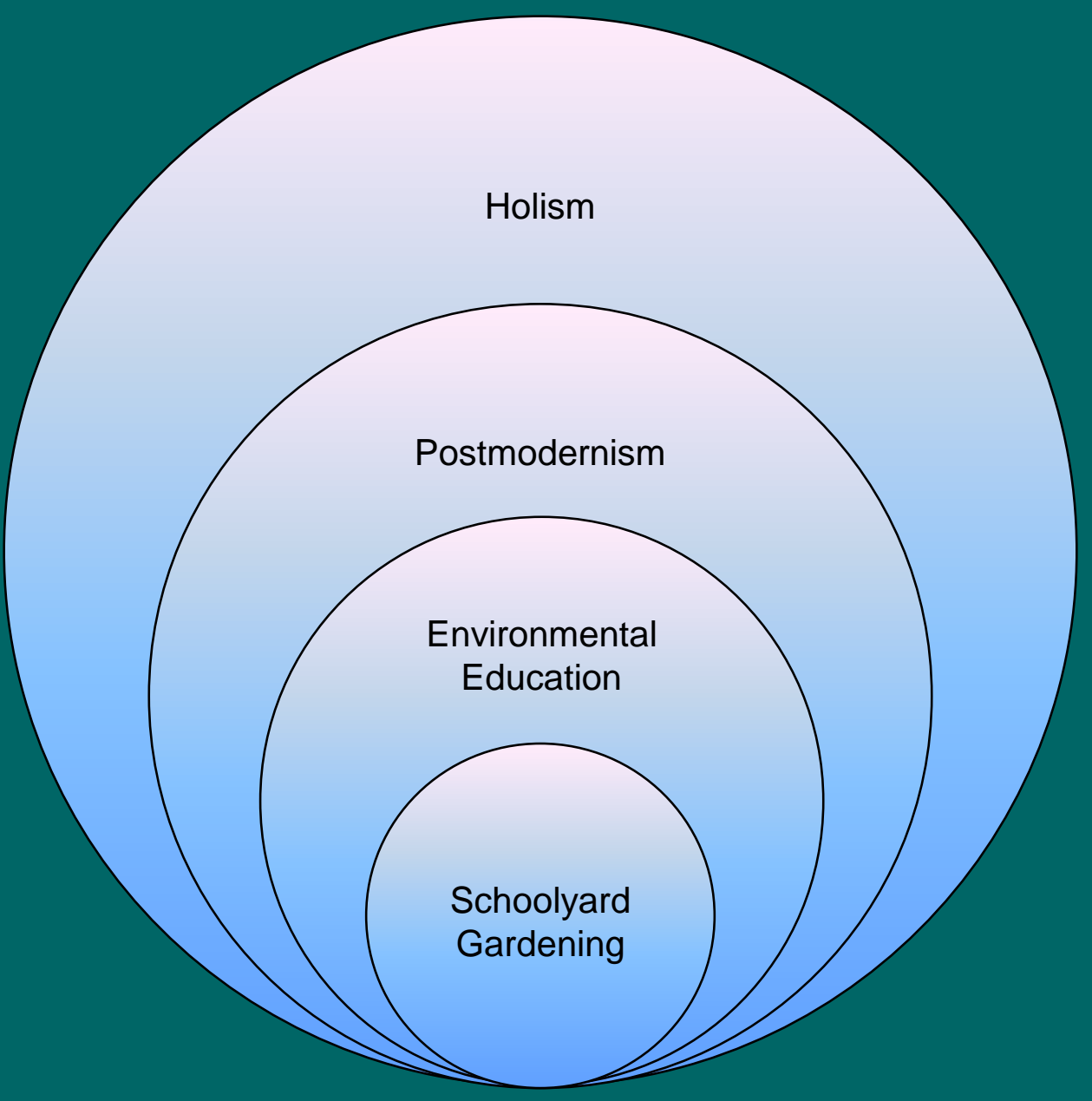

My conception of the interrelations of holism, postmodernism, environmental education, and schoolyard gardening. Drawing by Donia Zhang 


\section{Holism in Schoolyard Gardens}

Some educators consider that the schoolyard gardening movement situates within the holistic educational philosophy and the multiple intelligences theory that stress the development of the whole child. The Key books on holistic education include:

$>$ Ron Miller's What Are Schools For? (1997)

$>$ John P. Miller's The Holistic Curriculum (1996)

Howard Gardner's Multiple Intelligences $(1993,1995)$

Tobin Hart's The Secret Spiritual World of Children (2003)

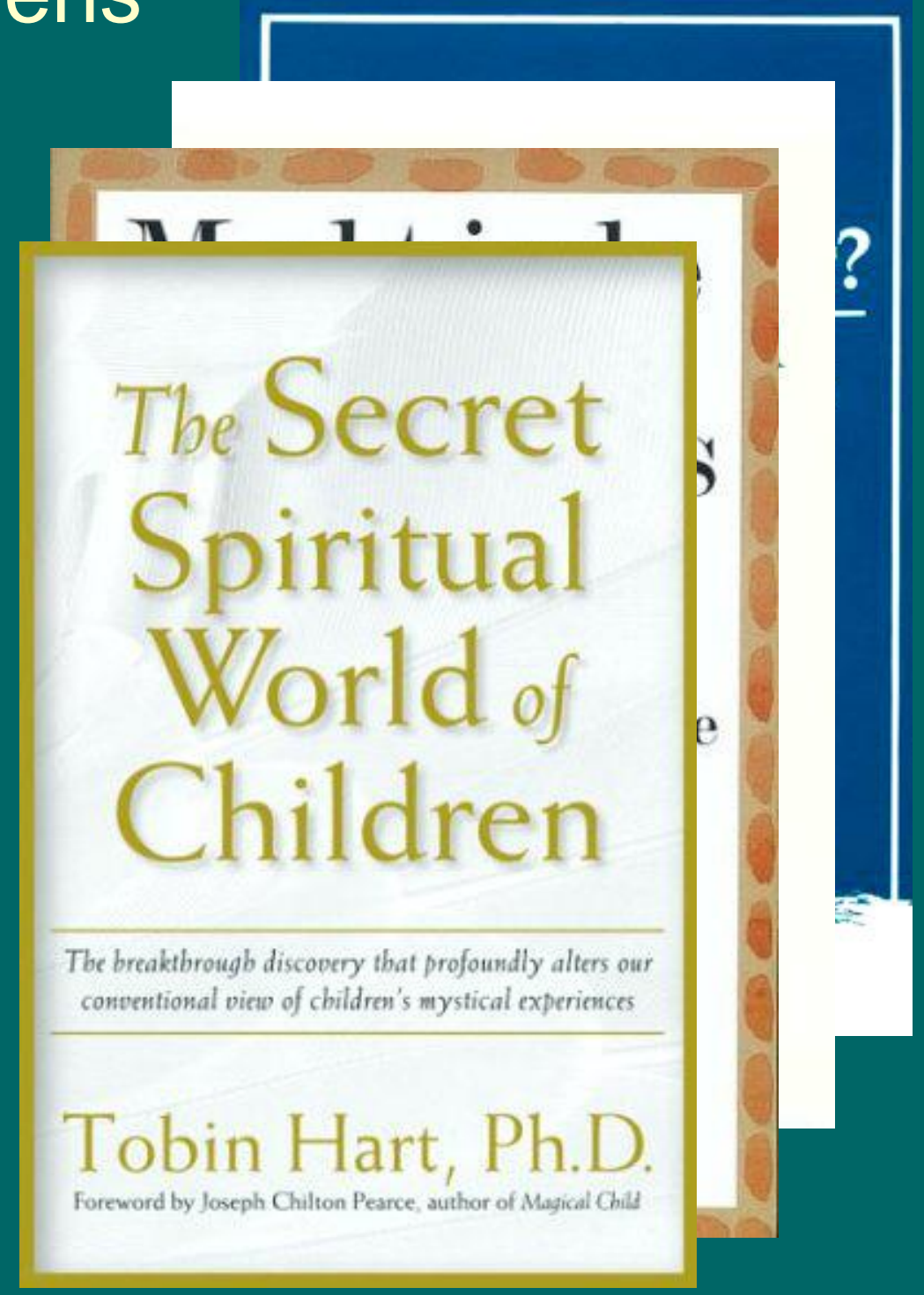




\section{History of Children Gardening}

Some people may think that schoolyard gardens are something new that emerged recently in the 1970 s or 1980 s, but my literature research found:

$>$ Forest Colonies in Ancient India

$>$ Robert Louis Stevenson's A Child's Garden of Verses (1883/1981/1999)

$>$ Gertrude Jekyll's Children and Gardens (1908/1982/1990)

$>$ Frances Hodgson Burnett's The Secret Garden (1911/1938/1962/1990)

$>$ Carol Martin's A History of Canadian Gardening (2000)

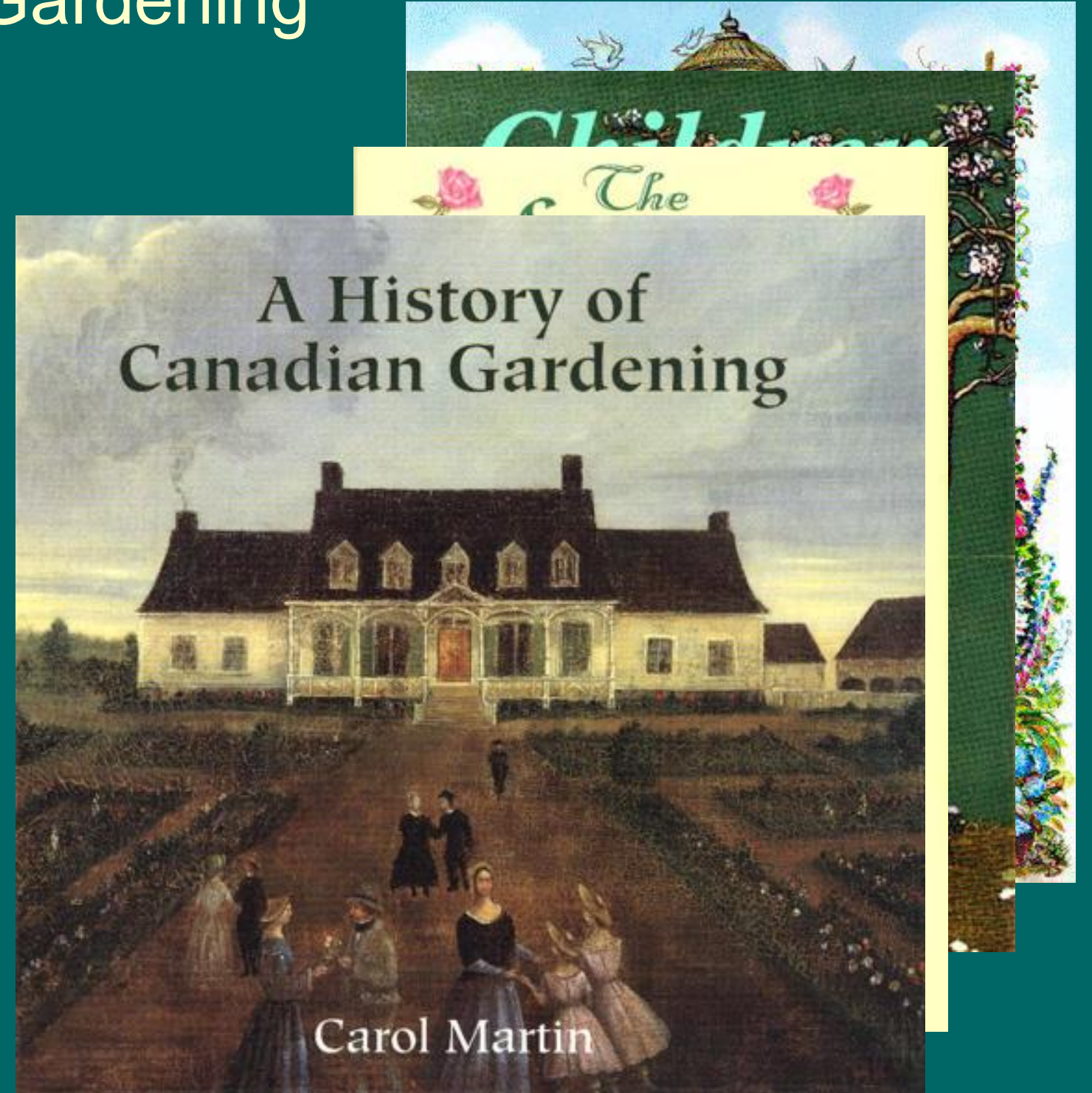




\section{History of Children Gardening (continued)}

War Gardens during World War I

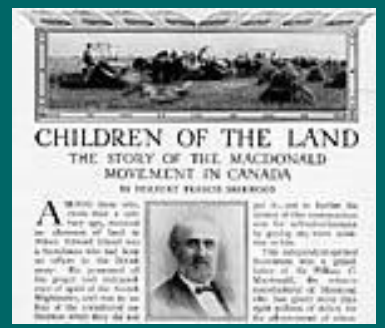

Children of the Land: The Story of the Macdonald Movement in Canada

by Herbert Francis Sherwood (1910)

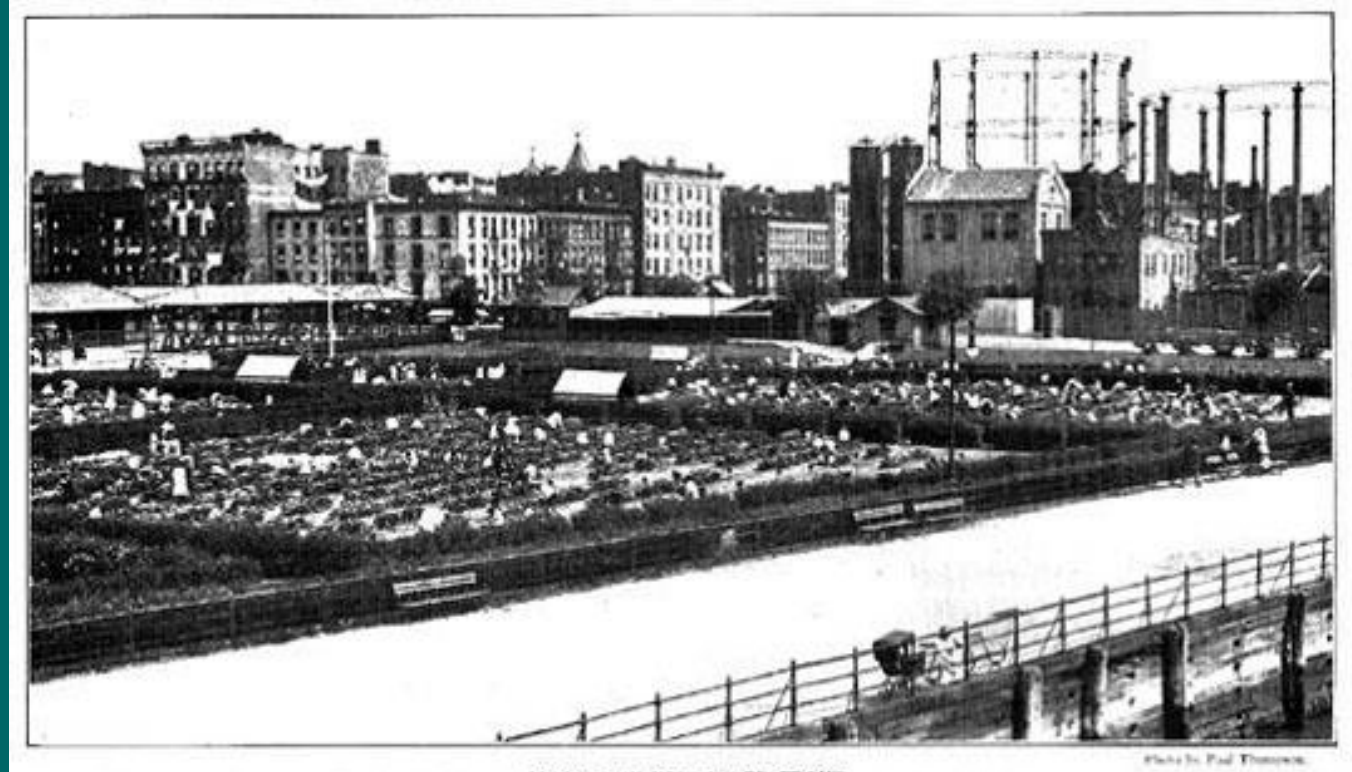

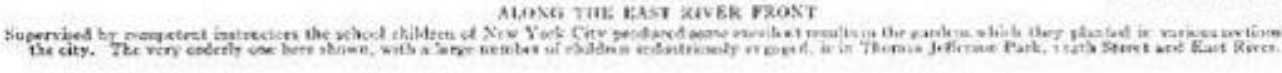

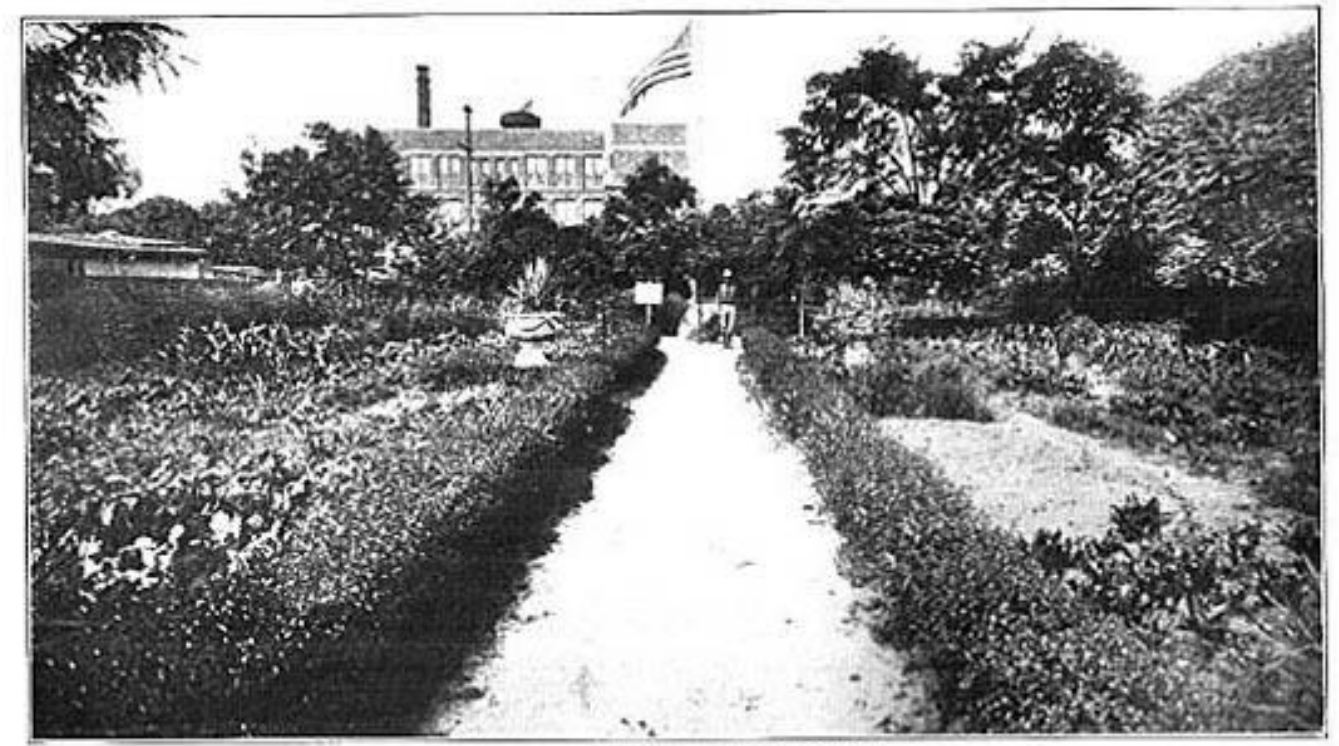

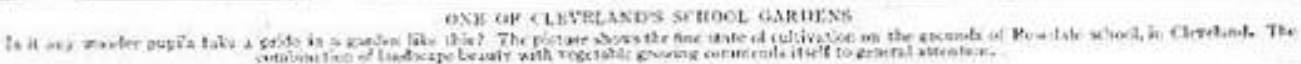

Rosedale School Gardens in Cleveland, Ohio
Along the east riverfront, the United States School Garden Army produced some excellent results in the gardens in various sections of the New York City, such as the one in Thomas Jefferson Park, 114th Street and East River

\section{Children's Gardening} by Department of Education (1912) Toronto, Ontario: L. K. Cameron

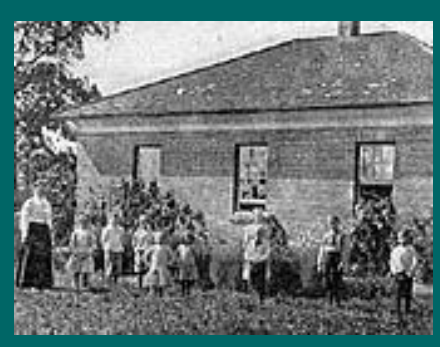

14 


\section{History of Children Gardening (continued)}

Victory Gardens during World War II

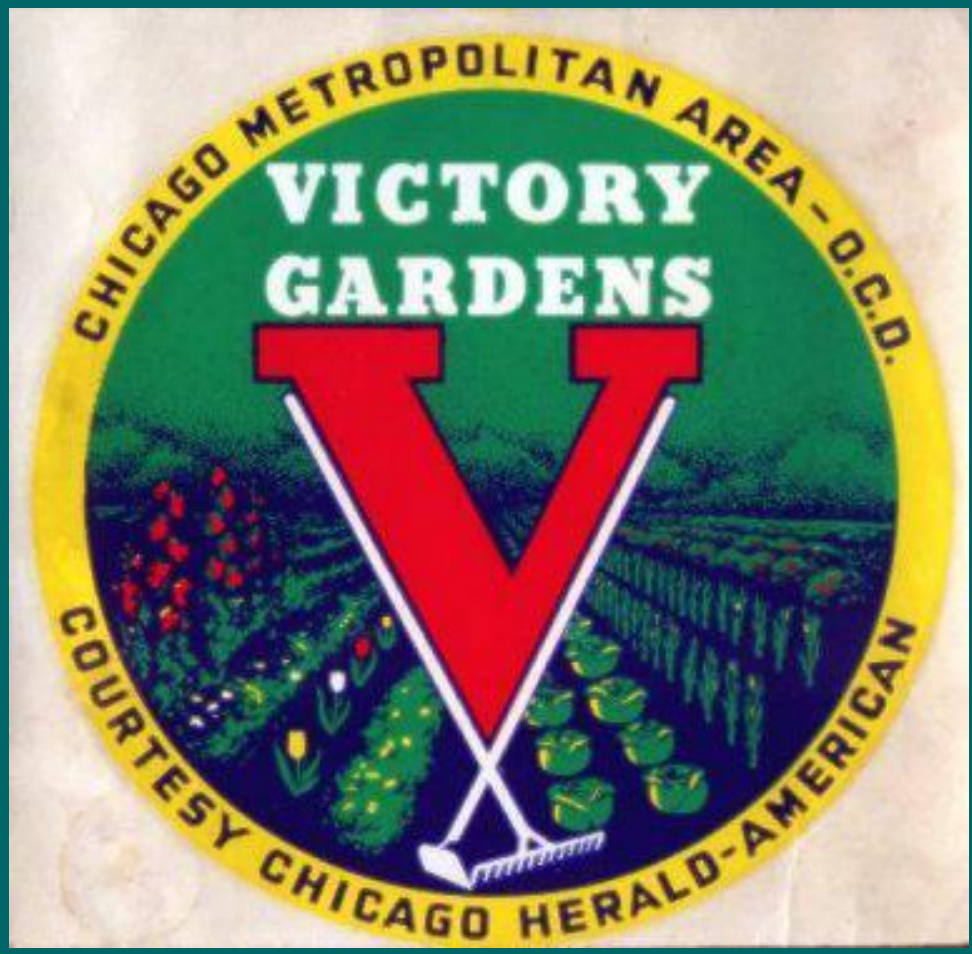

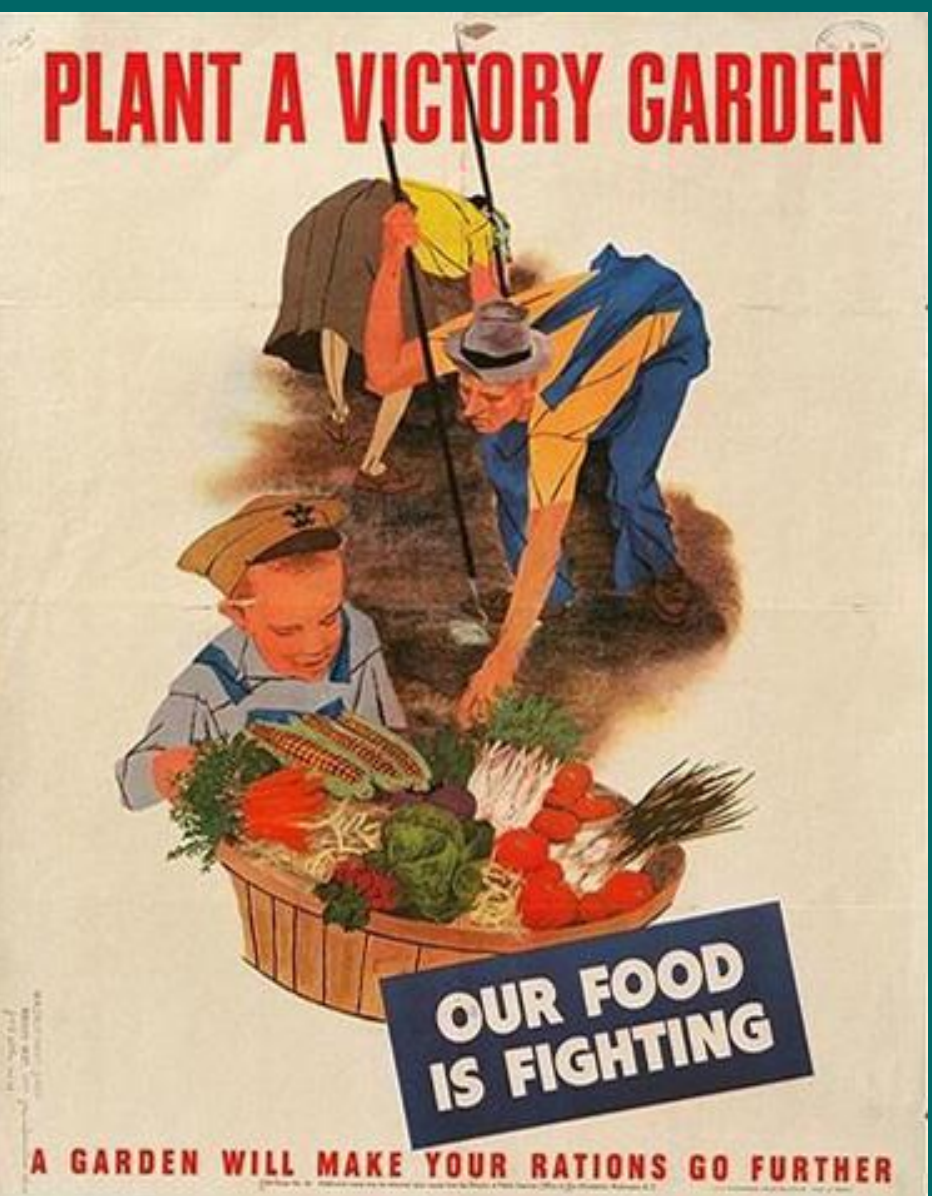




\section{Continuity of Schoolyard Gardening}

My literature review shows that student participation in schoolyard gardening can enhance their:

$>$ Healthy eating habits

$>$ Cultural appreciation

$>$ Social, behavioral, and moral development

$>$ Environmental consciousness and ecological literacy

$>$ Academic learning 


\section{Literature Review}

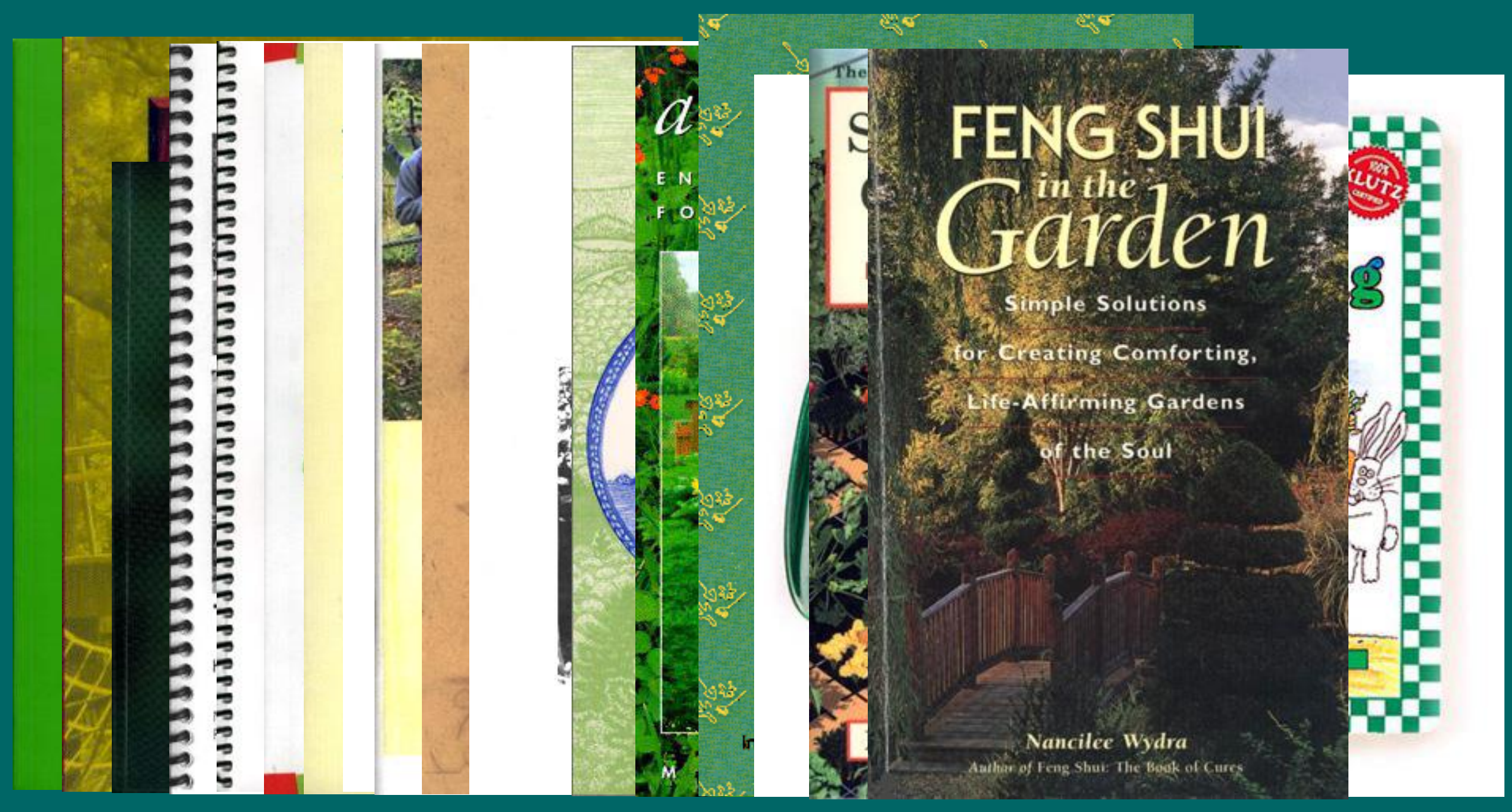




\section{Research Design: Transformative Research}

The research design was guided by the principles of transformative research (Deshler \& Selener, 1991) in these ways:

1. Ethical - paying special attention to the preservation of environmental sustainability

2. Empowering - promoting the conservation and proliferation of different forms of life

3. Holistic - emphasizing, identifying, and revealing relationships and interconnectedness between the part and the whole, the micro and the macro, and the local and the global 


\section{Data Collection}

It is a collective case study using interviews and site photos as the main data collection method.

$>$ Since the research involved human participants, ethics approval from Brock University Research Ethics Board (REB) was received on April 1, 2005, and from the Toronto District School Board External Research Review Committee on April 25, 2005

$>$ Email invitation was sent to about 240 TDSB schools in April 25 May 7, 2005, along with my Letter of Invitation, Consent Form, Interview Questionnaire, and later, Interview Schedule

$>$ Interviews were conducted in May 13 - June 10, 2005

$>$ There were 16 interview participants 


\section{Interviewees}

TDSB schools:

$>2$ principals, 3 most involved teachers, 2 less involved teachers, 3 involved parents that are associated with the three case study schools (plus 1 additional parent at a fourth school that is not part of the case studies)

TDSB/Evergreen representatives:

$>$ A district-wide coordinator of Environmental Education for the TDSB

$>$ A TDSB/Evergreen school ground design consultant

$>$ A district-wide grounds team leader at TDSB for 21 years

$>$ A national learning grounds manager at Evergreen

$>$ An education officer at the Curriculum and Assessment Policy Branch of the Ontario Ministry of Education 


\section{Data Analysis}

The data analysis applied Creswell's (1998) qualitative data analysis framework:

$>$ Within-Case Analysis

$>$ Cross-Case Analysis

$>$ Holistic Analysis

Within each analysis, data were further organized under four subsections:

1) Amount of Student Participation

2) Enabling Factors for Student Participation

3) Limiting Factors for Student Participation

4) Ways to Support Student Involvement 


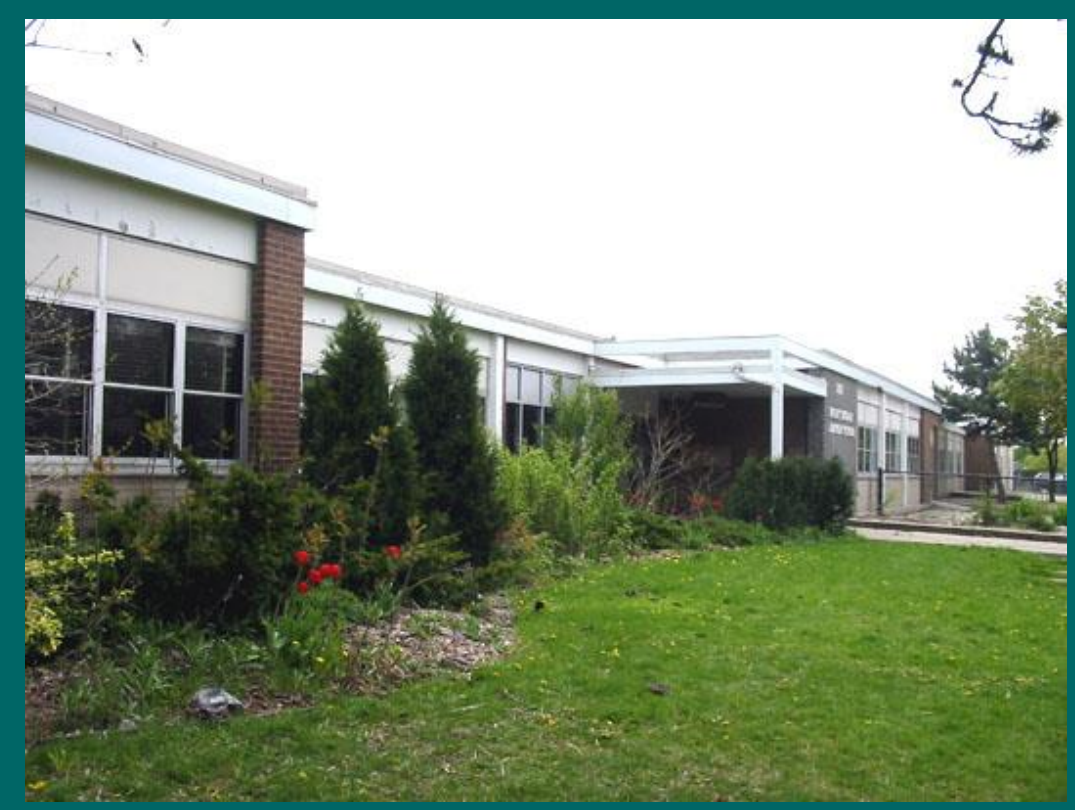

School A front garden

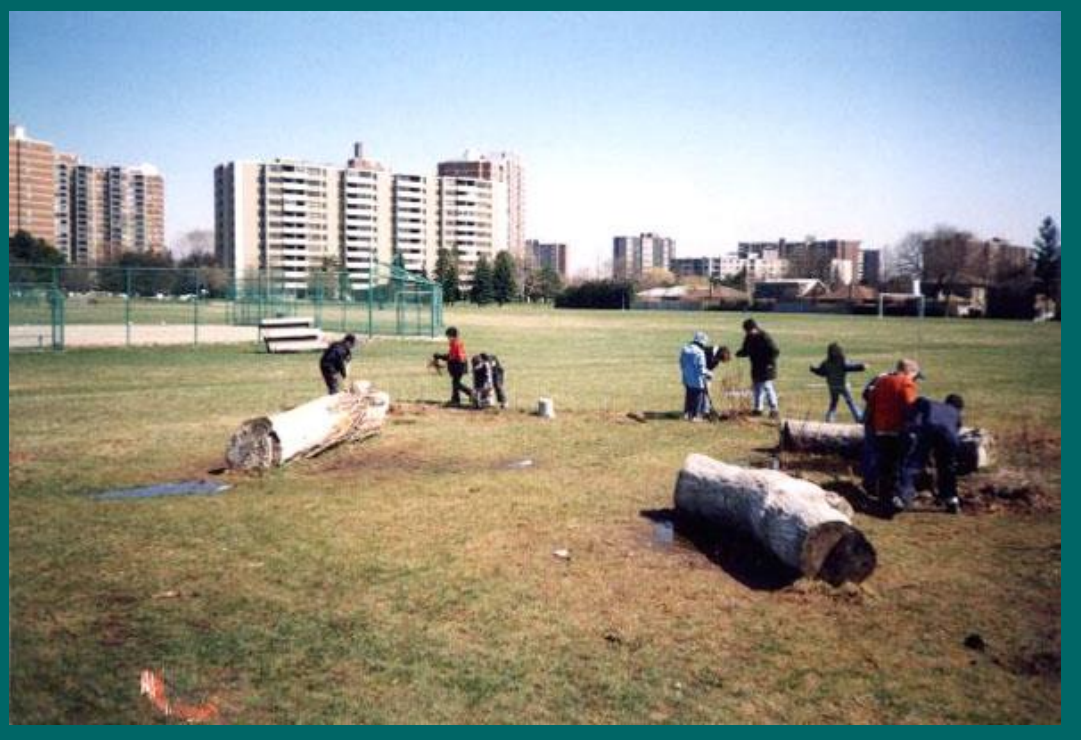

School A schoolyard, 2000

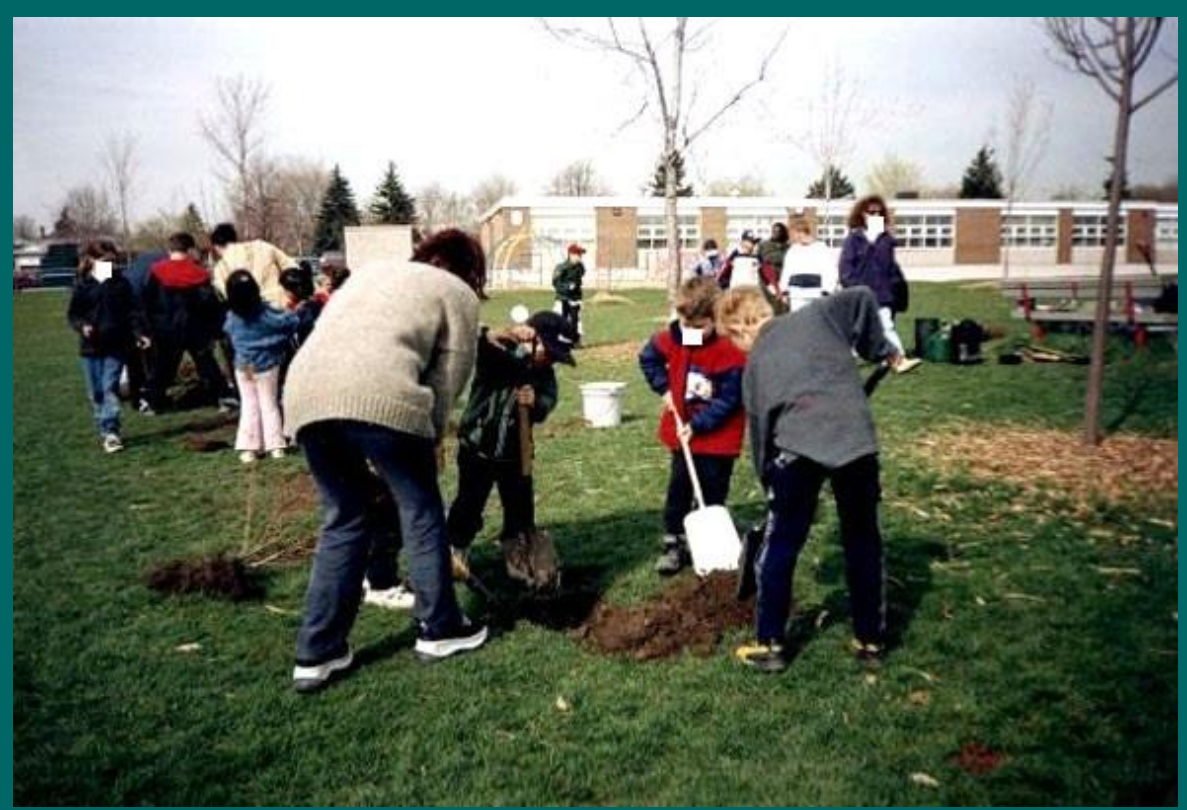

School A planting day

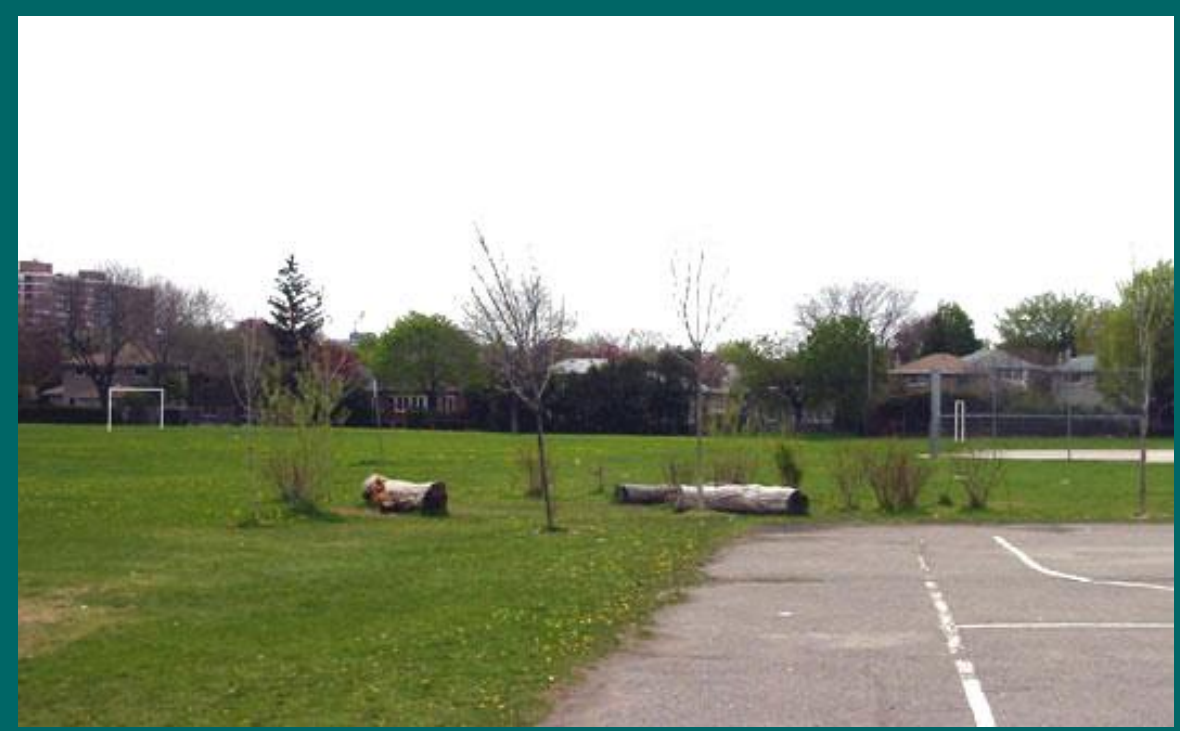

School A schoolyard, May 2005

22 


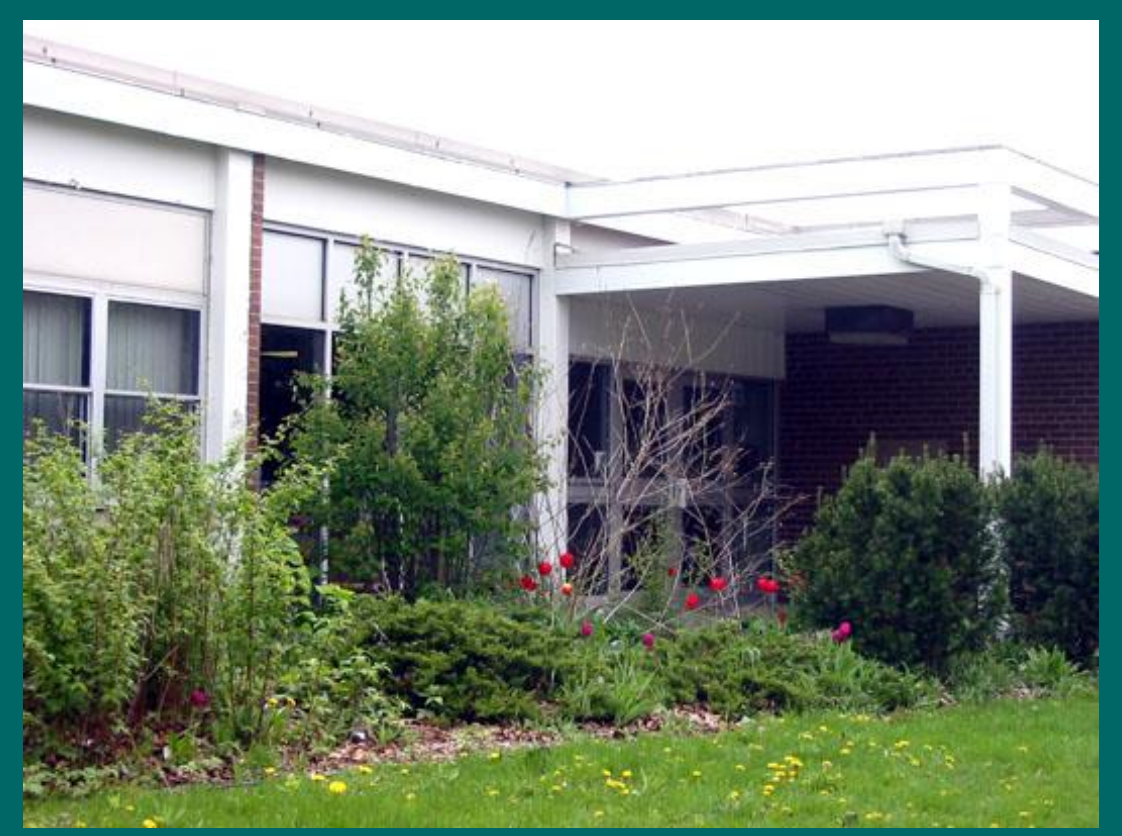

School A front garden

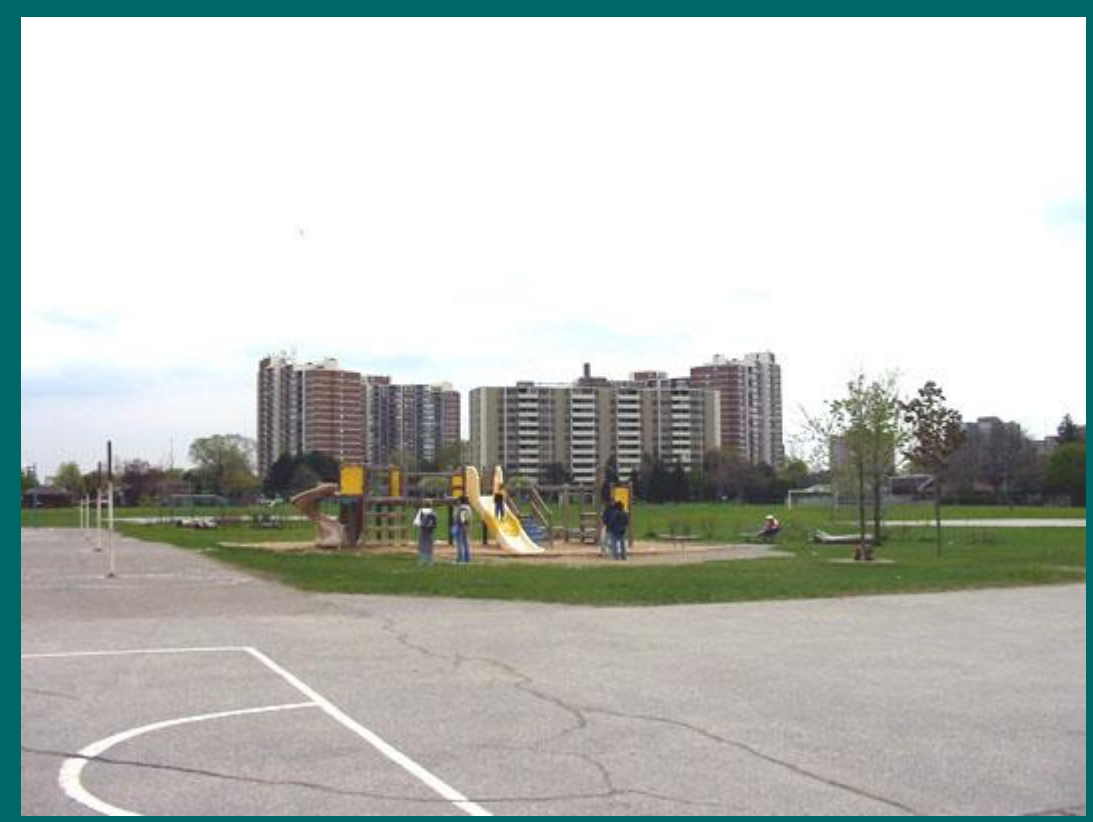

School A playground

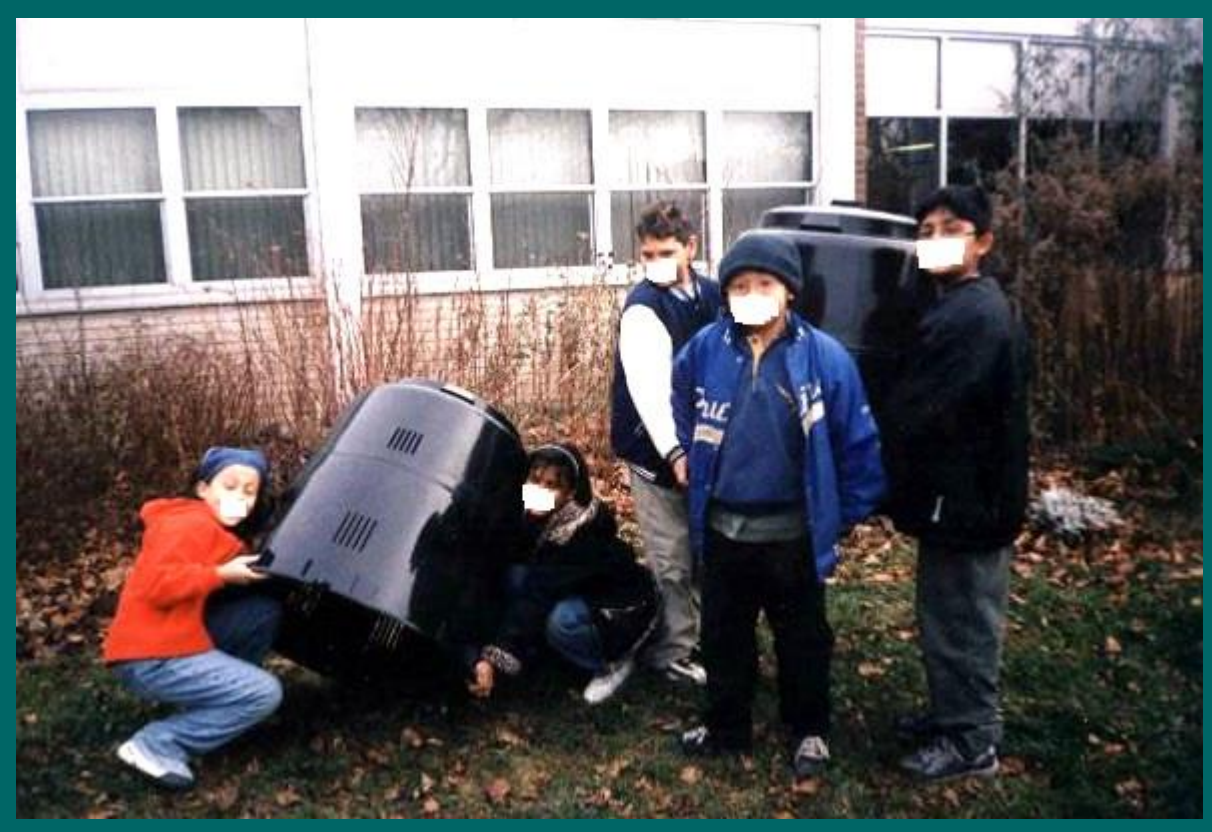

School A student composting

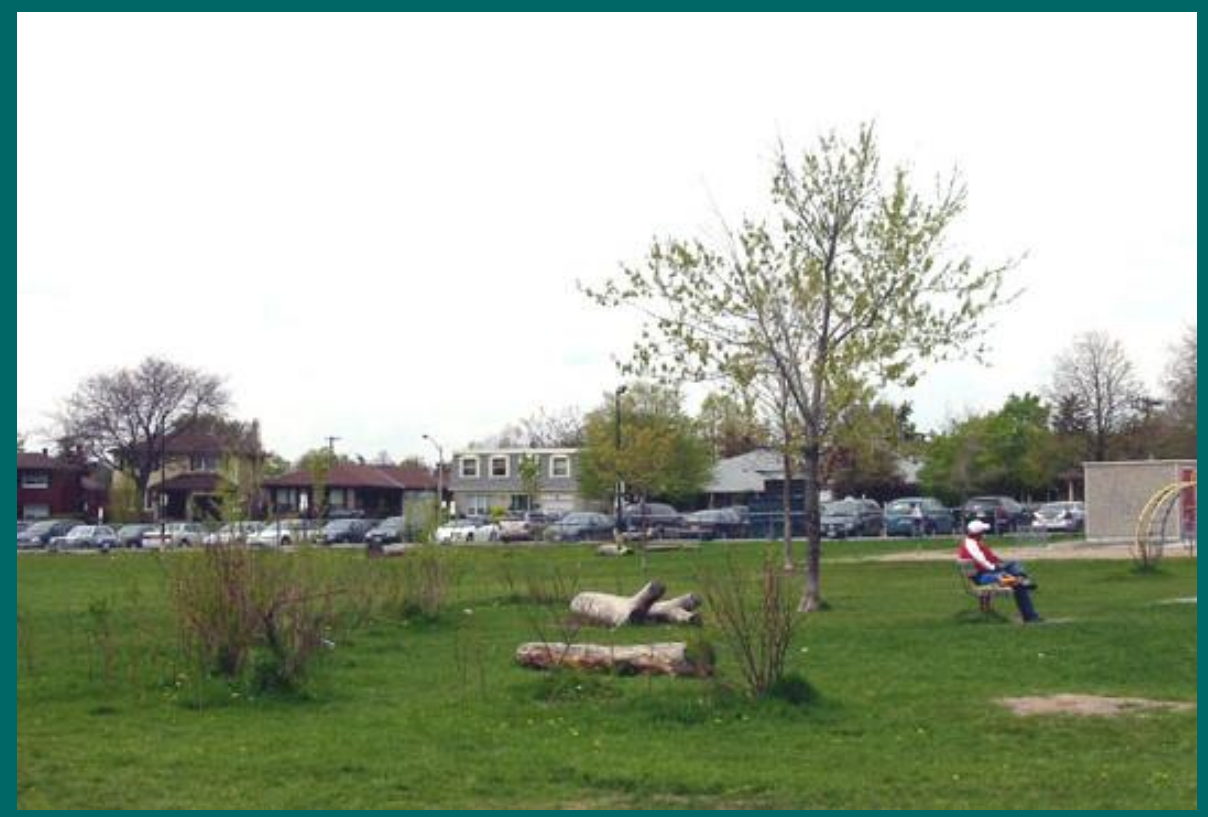

School A schoolyard, May 2005 


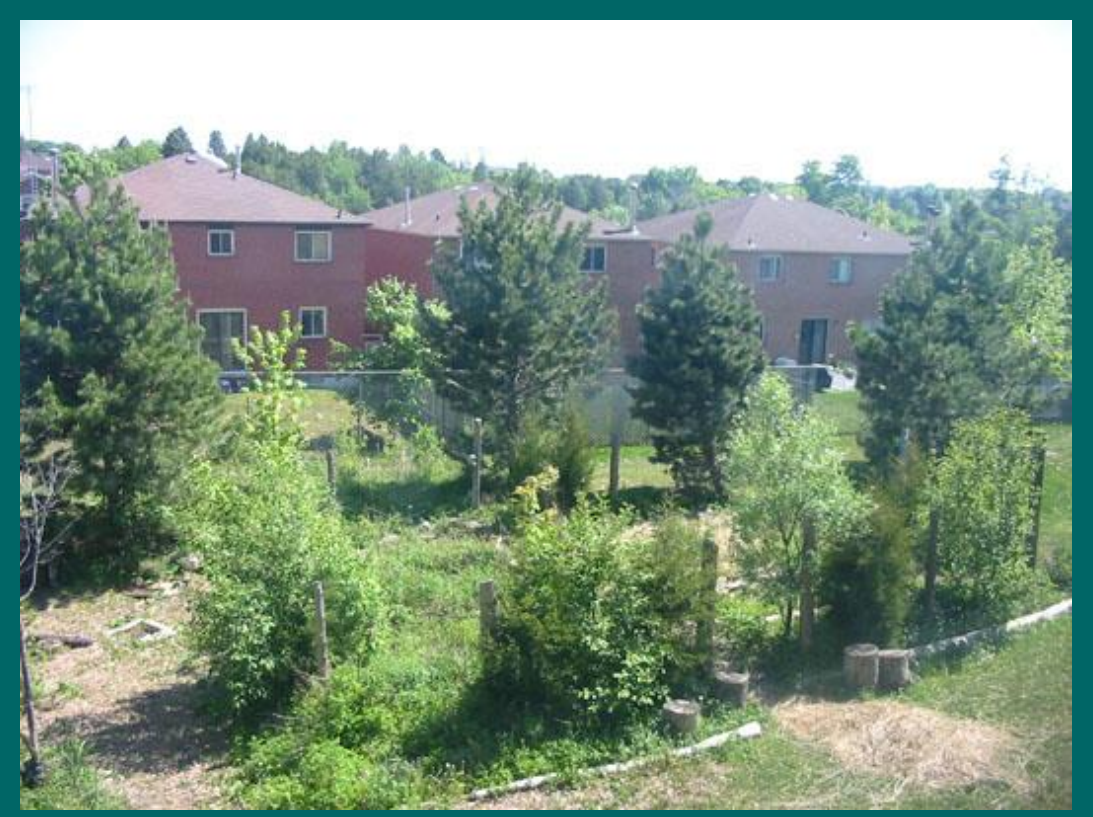

School B butterfly garden, May 2005

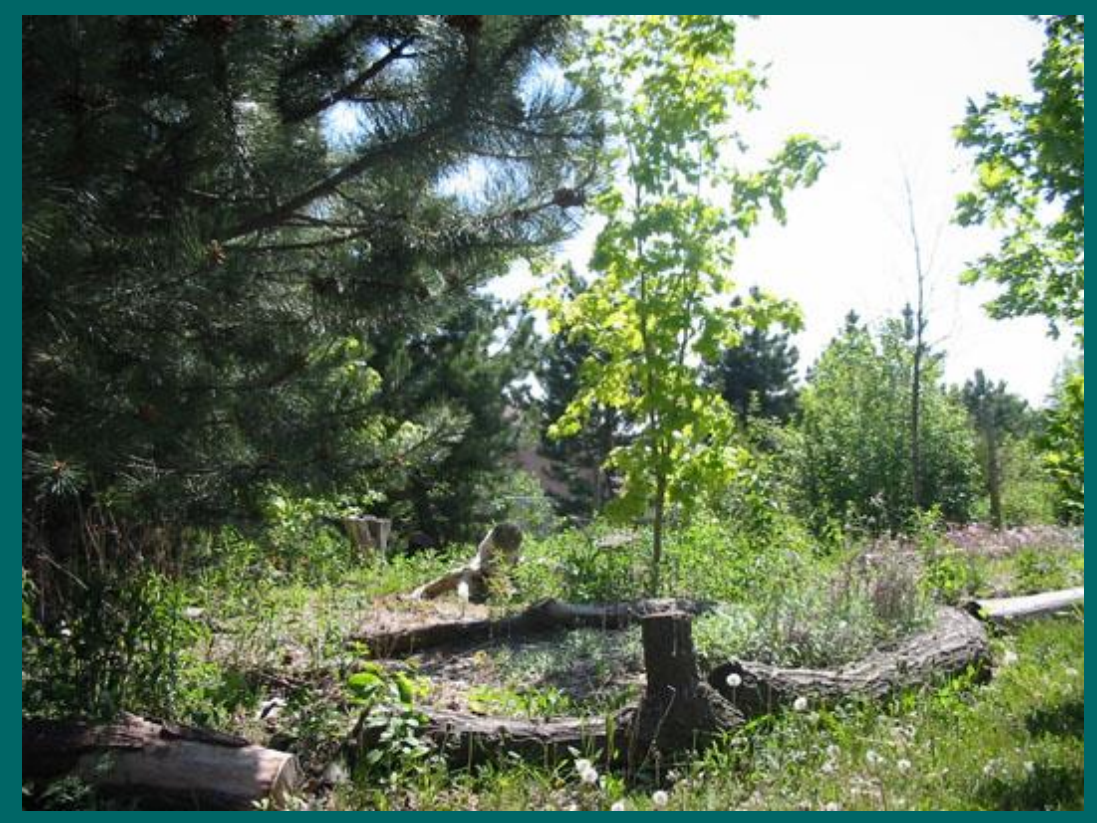

School B butterfly garden

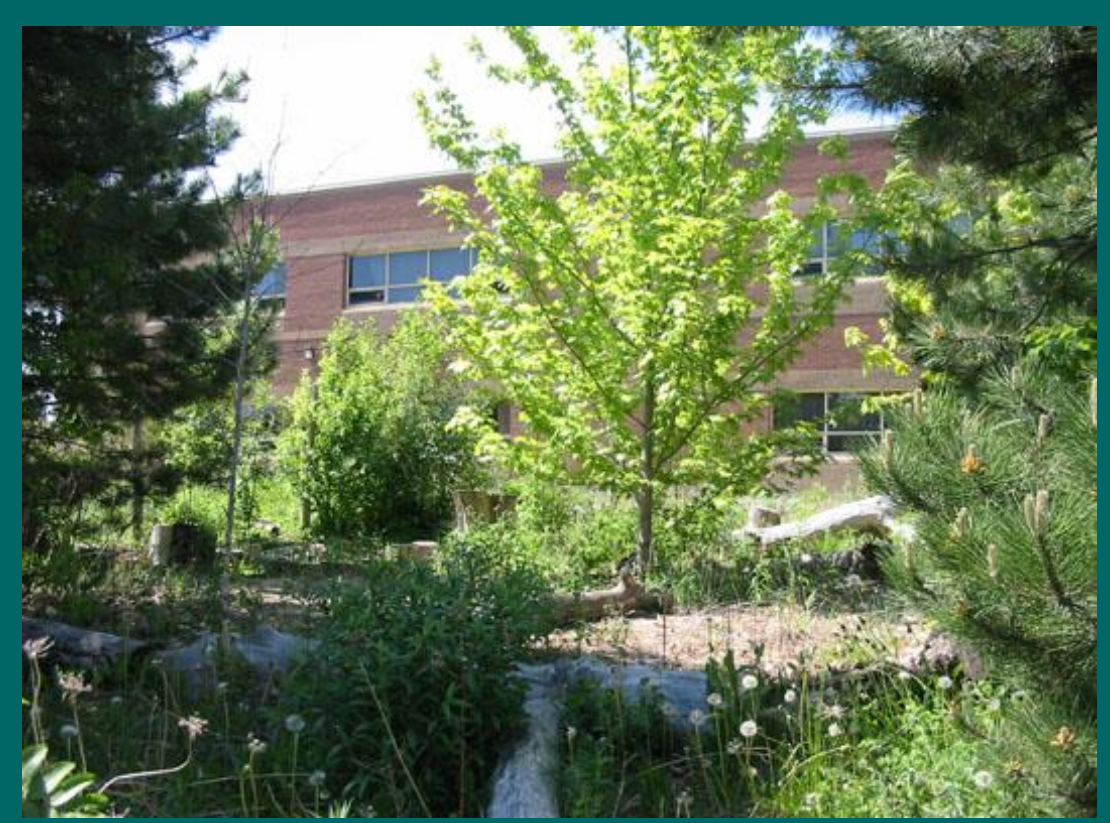

School B butterfly garden

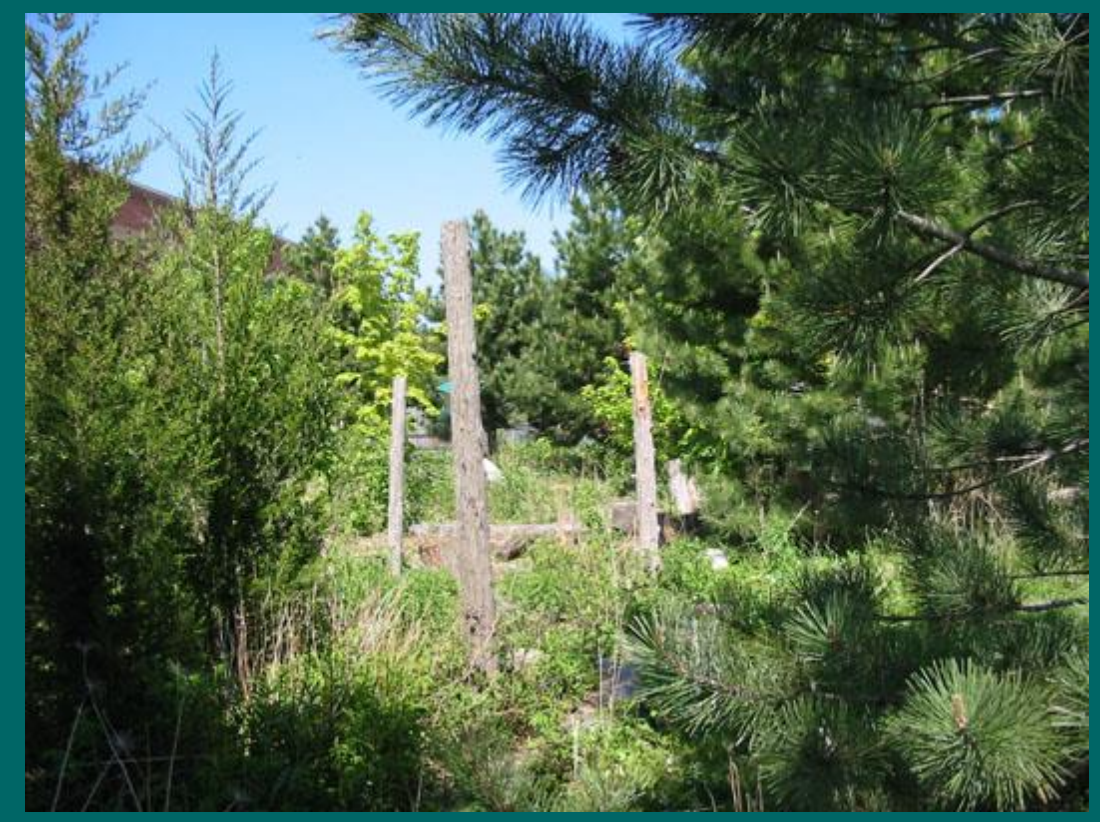

School B butterfly garden 


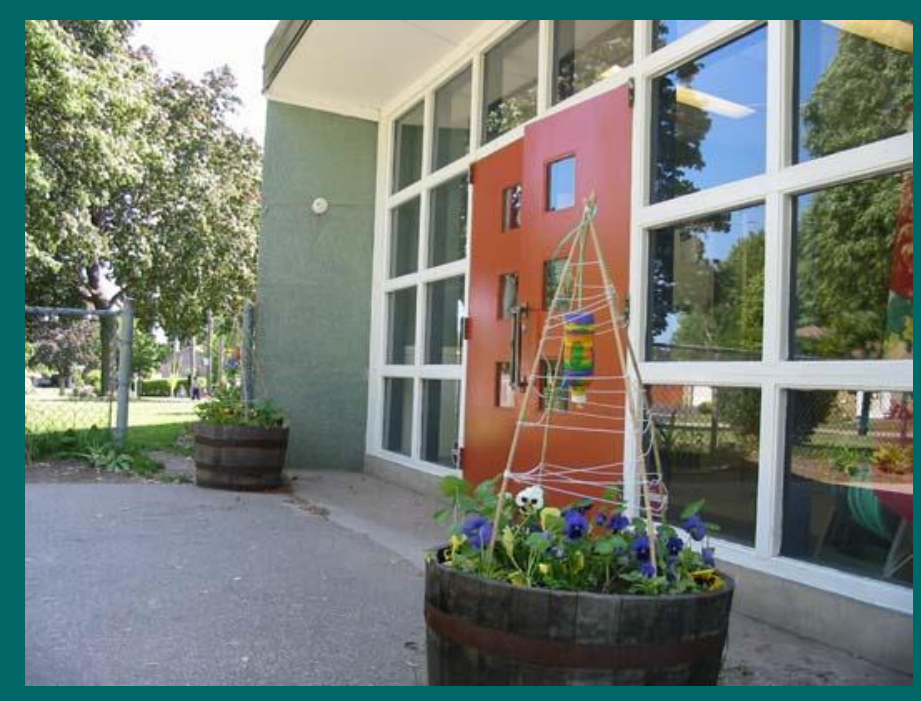

School C front entrance

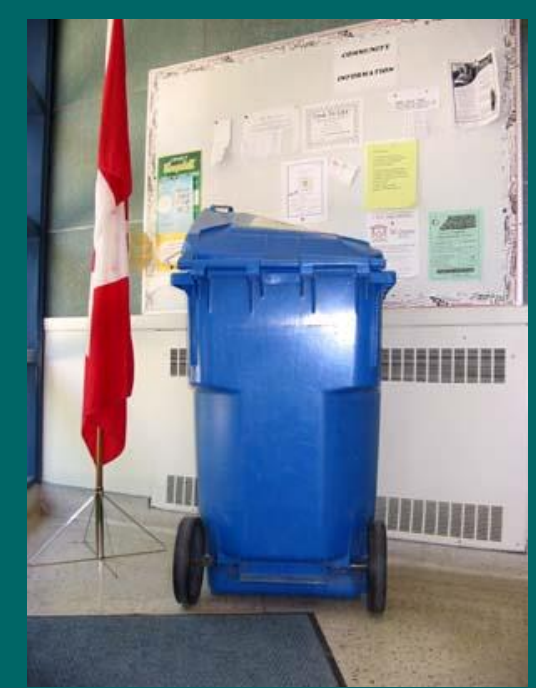

Paper recycle bin

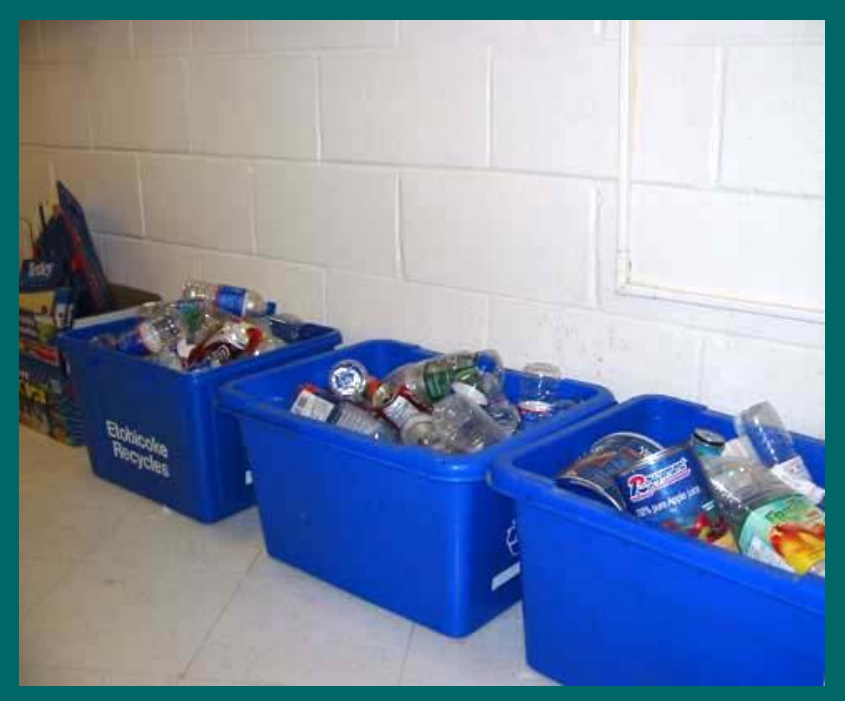

Recycle bins

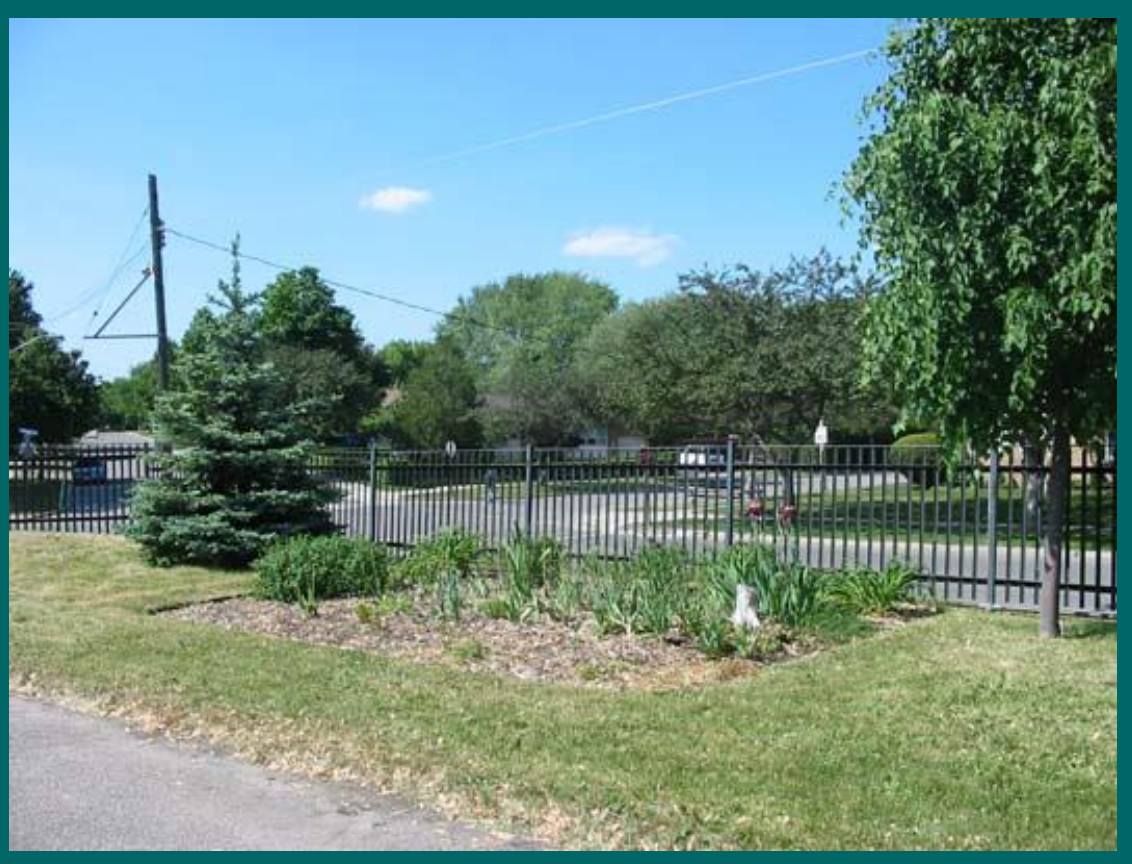

School C kindergarden, June 2005

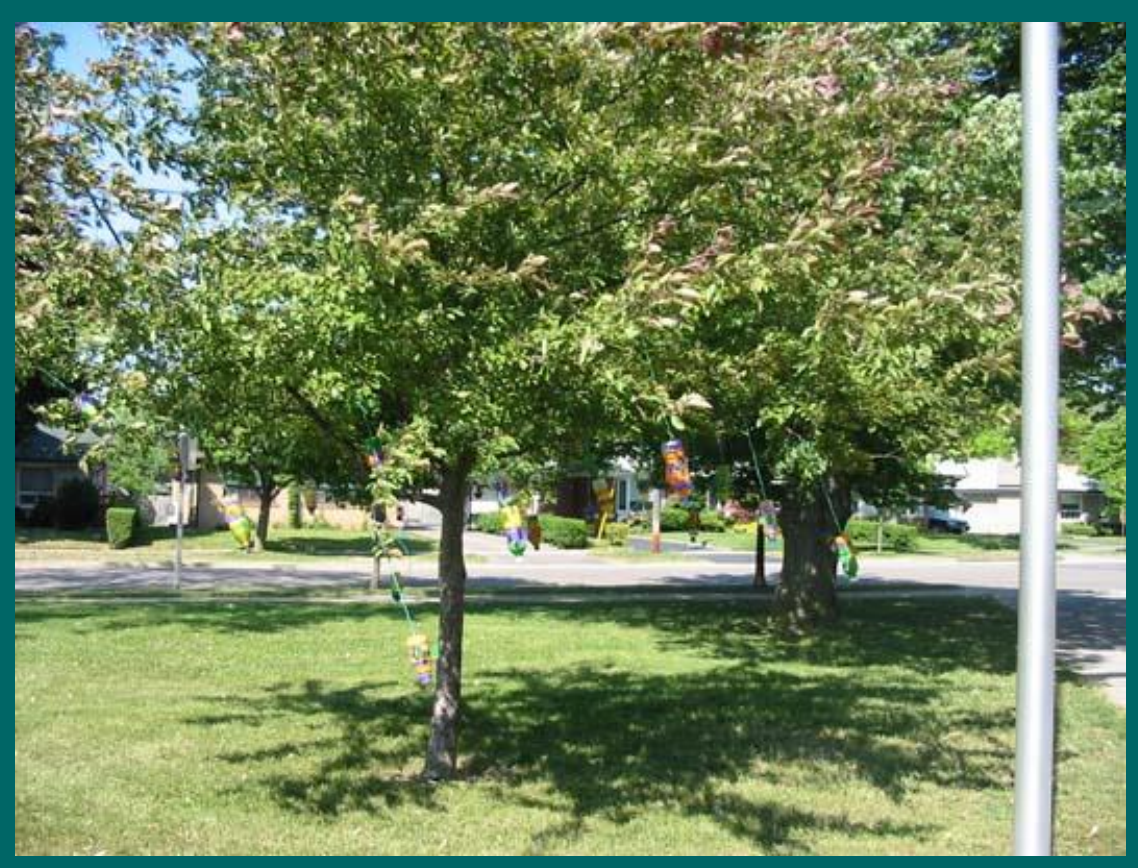

Hanging tree with waterballs 


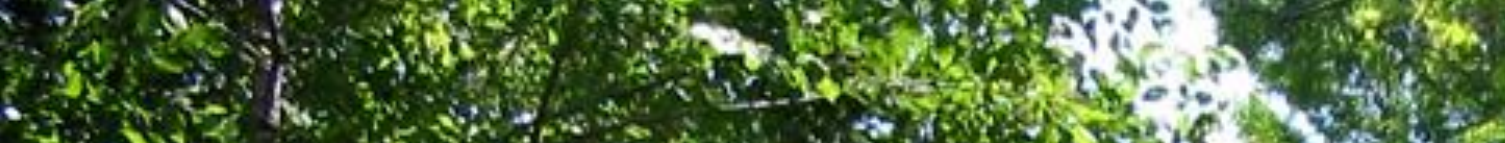

-

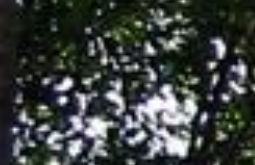

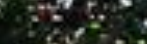

$$
\text { in: }
$$

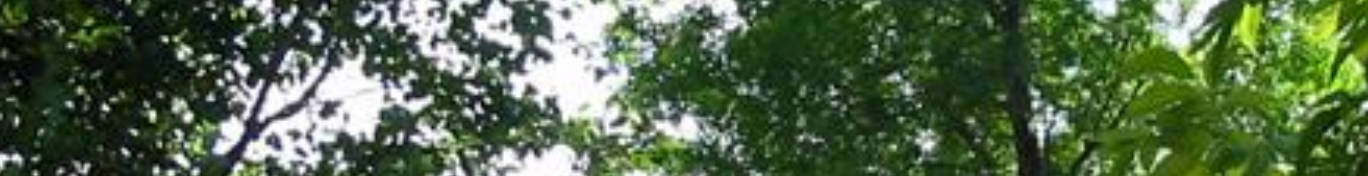

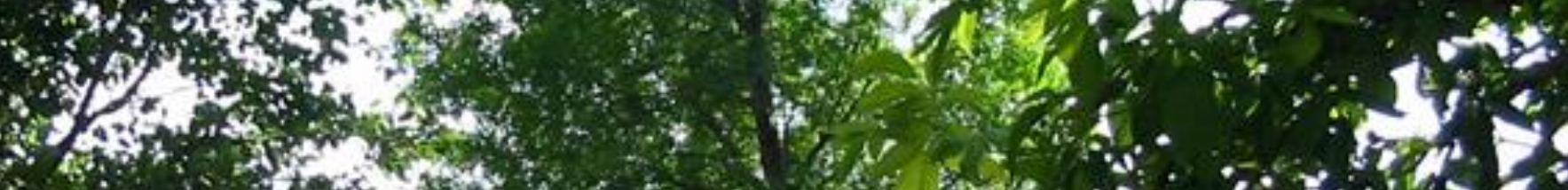

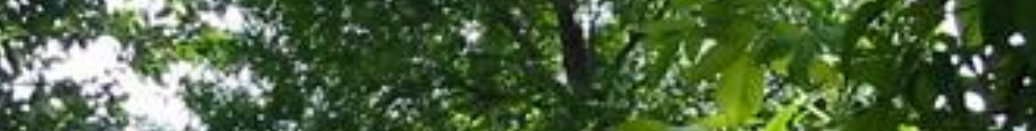
(3)

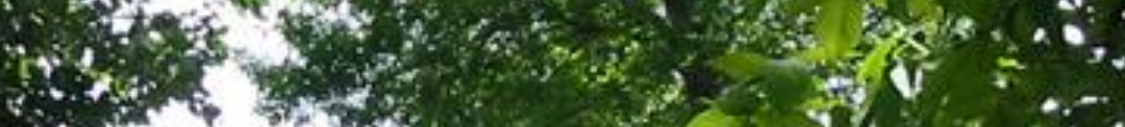

$\therefore$ A

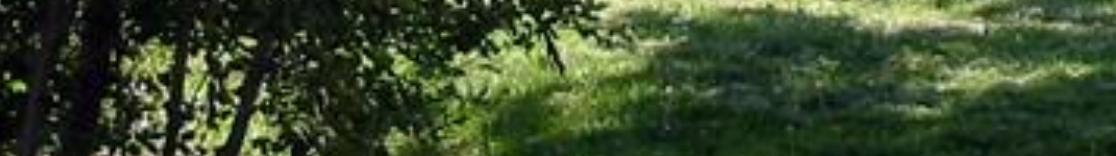

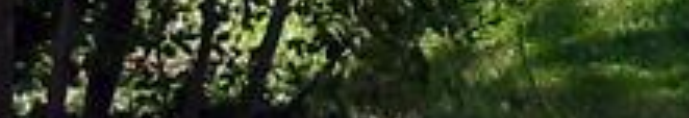

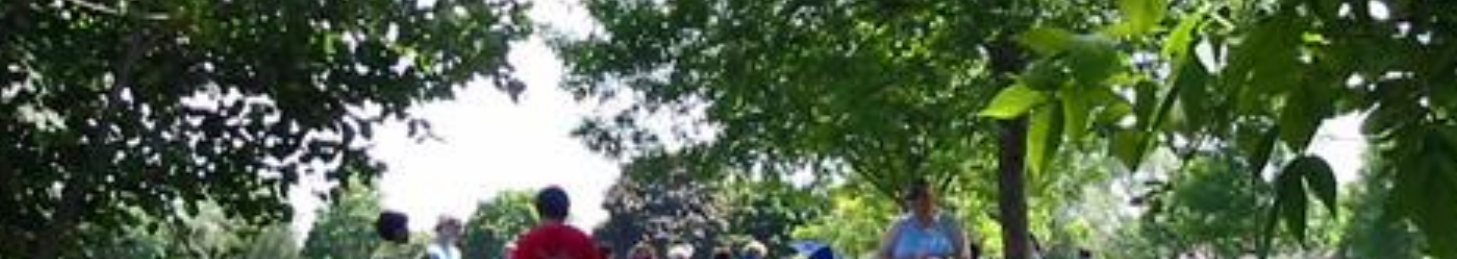




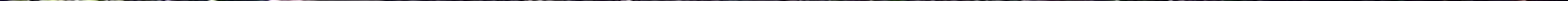




\section{Key Findings}

The following theme, enabling and limiting factors are repeatedly emphasized by the three participating schools:

$>$ Typically, students were not involved in the initial planning or design stage of the schoolyard gardening project

$>$ Common enabling factors are teacher's initiative and commitment, principal's leadership and support, parental involvement and donations, and the TDSB's EcoSchools program and workshops

$>$ Common limiting factors are time, money, and the Union's "work-to-rule" issue 


\section{Key Findings (continued)}

Ways to support student involvement in schoolyard gardening include:

$>$ Teachers integrating gardening into the curriculum

$>$ Parents making donations to the school and creating a family gardening culture

$>$ Principals supporting in money or budget and taking the lead

$>$ TDSB providing funding, awards, incentives, and more maintenance

$>$ Ontario Ministry of Education supplying funding, curriculum link, and teacher training 


\section{Reflections}

Some interesting and surprising findings from the research are as follows:

$>$ Curriculum as Dual Factor

$>$ Community Gardening Culture as Dual Factor

$>$ Gardening Club as Important Enabling Factor

$>$ Children Educating Parents

$>$ TDSB Hiring More Grounds Crews

$>$ More Publicity for the TDSB's Publications

$>$ Consistency with Dyment's Findings (2004) 


\section{Implications}

In his book, Children's Participation (1997), Roger Hart used a ladder as a metaphor to illustrate the different degrees of children's initiation and collaboration when working on environmental projects with adults.

The ladder contains 8 rungs, with the lowest representing the least participation and the first 3 rungs are non-participation; they are unacceptable.

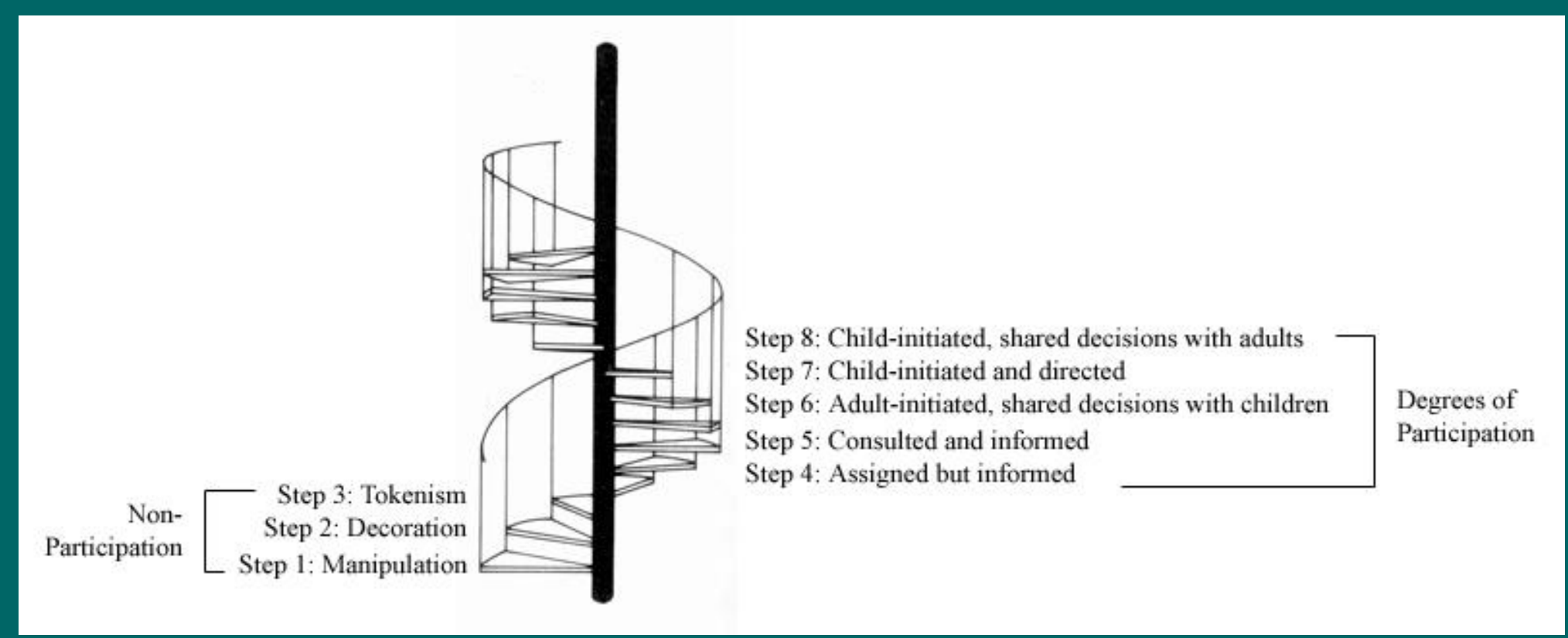

Roger Hart's Ladder of Children's Participation (1997). Reannotated by Donia Zhang 


\section{Implications (continued)}

From each school's participants, I found that:

School A: "Assigned but Informed" (Rung 4)

School B: "Consulted and Informed" (Rung 5)

School C: "Adult-Initiated, Shared Decisions with Children" (Rung 6)

During my visit to the three schools, I observed that this level of student involvement was well reflected in their garden conditions; the gardens at School C indeed looked better than the ones in School A and School B.

However, Hart (1997) advised that this ladder should not be used as a measure to create a sense of inferiority for children operating at lower levels. 


\section{Recommendations for Future Research}

$>$ Investigate student perceptions of their involvement in schoolyard gardening

$>$ Produce a practical manual on integrating all the curriculum areas with the schoolyard gardening project

Find plausible solutions on financing schoolyard gardening projects

$>$ Explore what the issues are between the Union and the Toronto District School Board and searching for ways of preventing the "work-to-rule" situation from happening again

$>$ Do longitudinal experimental research on the impacts of schoolyard gardening on the development of each child's naturalist intelligence, ecological intelligence, emotional intelligence, and spiritual intelligence

$>$ Explore if having a schoolyard garden may increase the general health level of the children and adults, and if it may reduce the absentee rate for both teachers and students at the same school 


\section{Recommendations for Future Practice}

Schoolyard Garden Planning: Using Square Foot Gardening

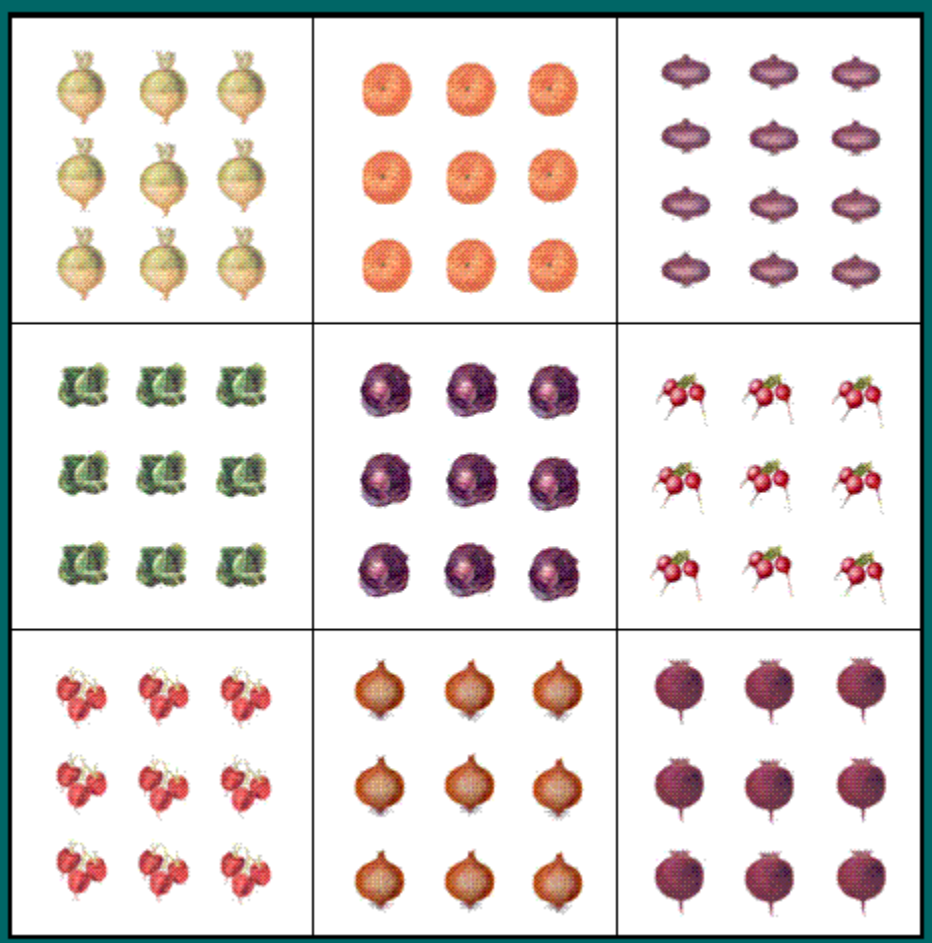

Mel Bartholomew's Square Foot Gardening (2005).

Redrawn by Donia Zhang 


\section{Recommendations for Future Design}

Schoolyard Garden Design: Using Feng Shui Concept (swing, water, cave-like places, rocks, stones, trees, tree houses, forts, dens, bush houses, seating, etc.)

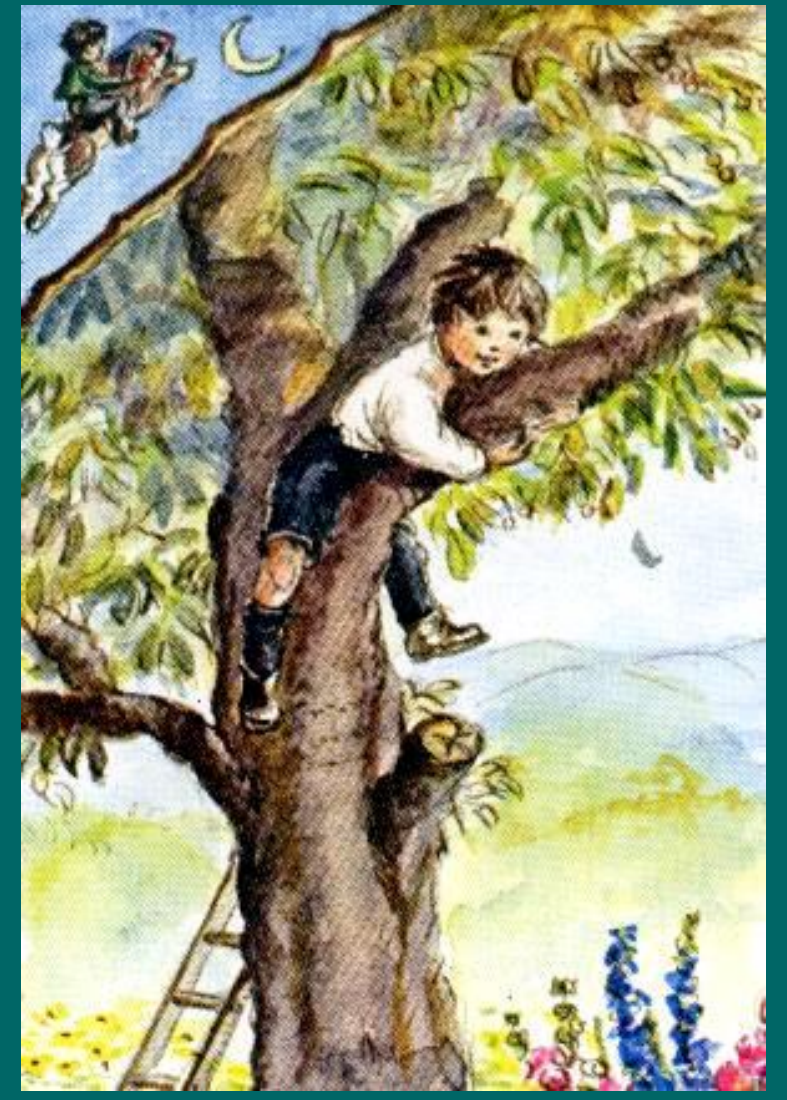

Image Source: A Child's Garden of Verses by Robert Louis Stevenson, illustrated by Tasha Tudor, 1981/1999, p. 15

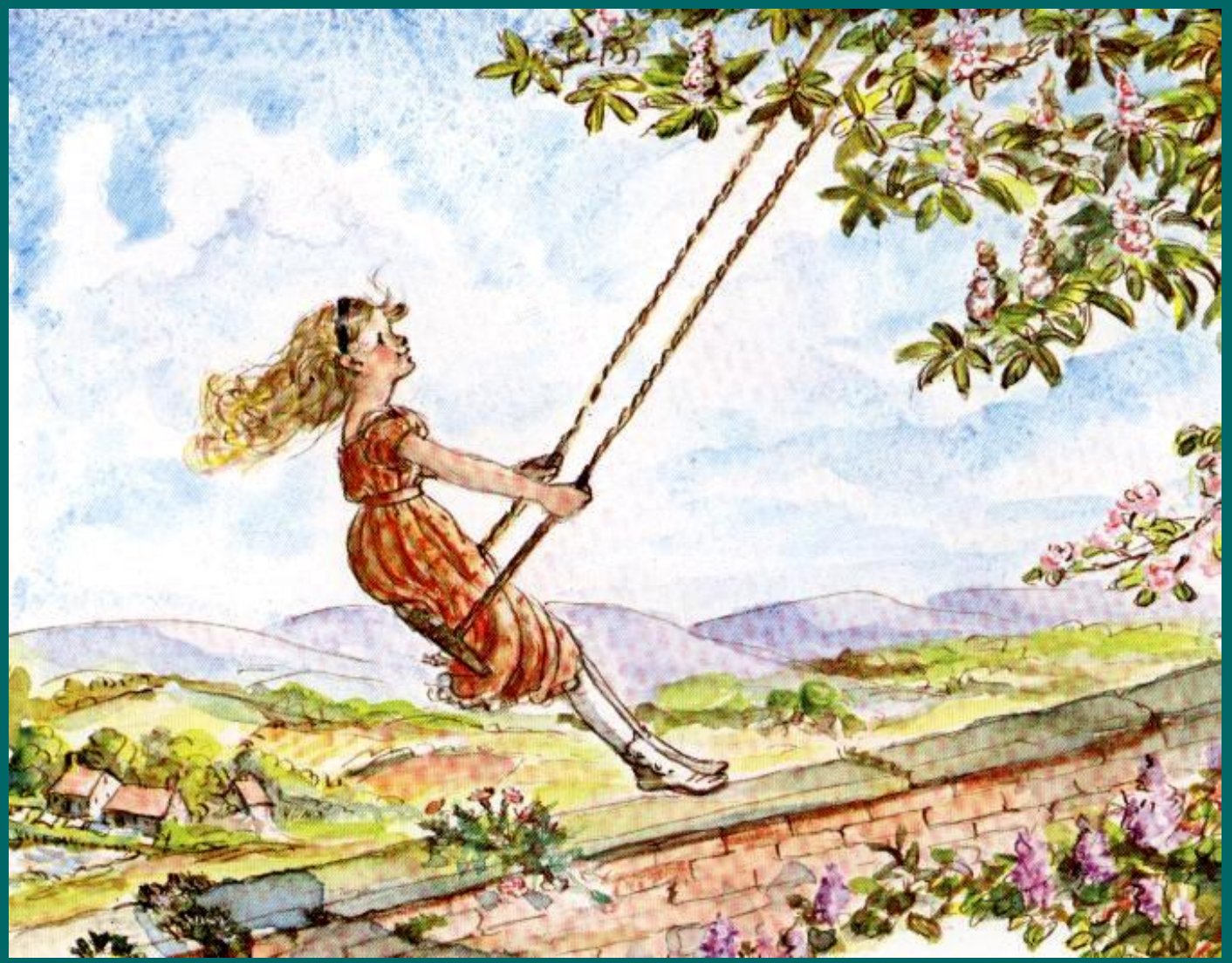

Image Source: A Child's Garden of Verses by Robert Louis Stevenson, illustrated by Tasha Tudor, 1981/1999, p. 36 


\section{Thank You}

Presentation based on my MEd thesis completed at Brock University (2003-2005), which has been published as a book, Schoolyard Gardening as Multinaturalism: Theory, Practice, and Product by VDM Verlag (2009). ISBN: 978-3639042023
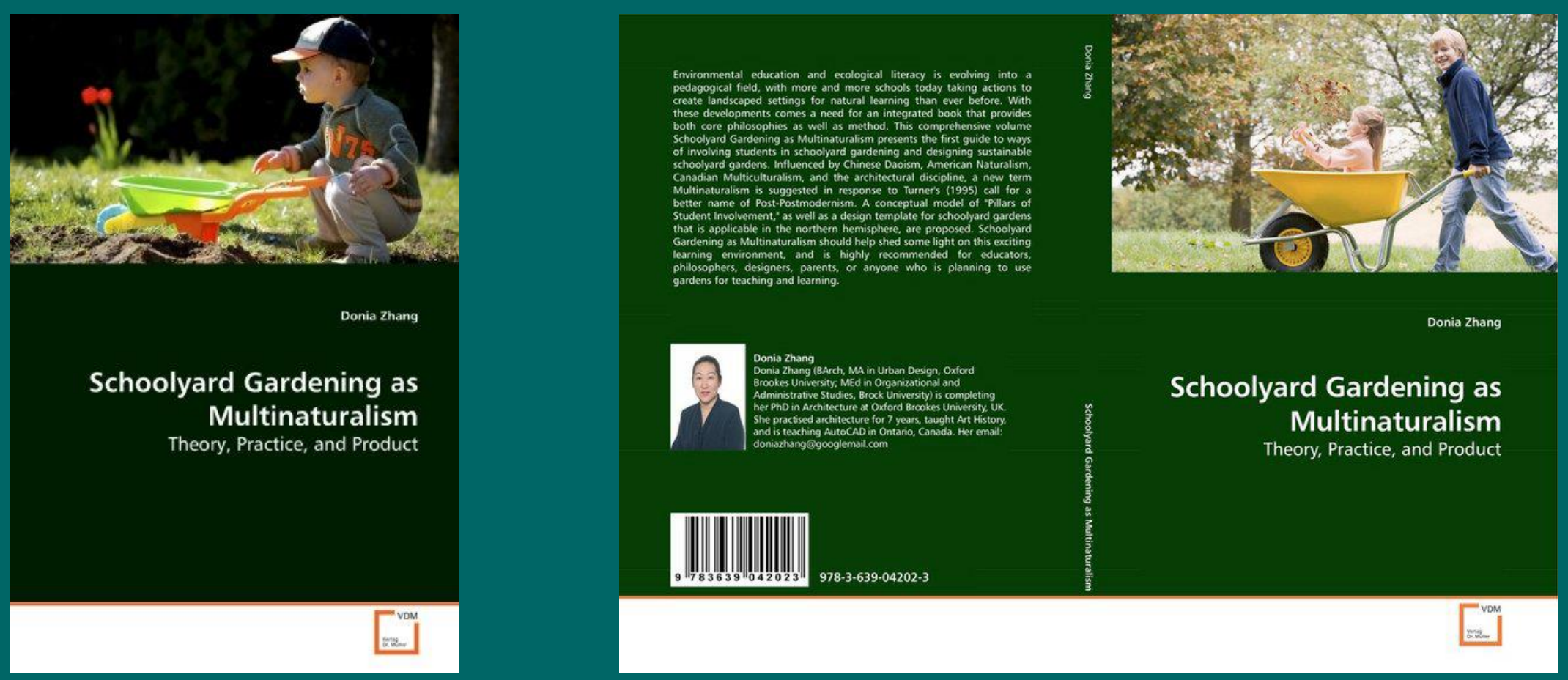